\title{
Klasik Türk Şiirinde Dolab-nâme Hakkında Mülahazalar
}

\section{The Considerations about the Dolab-nama Genre in Classical Turkish Poetry}

\author{
Türkan Alvan ${ }^{1}$ (1)
}

${ }^{1}$ Fatih Sultan Mehmet Vakıf Üniversitesi, Edebiyat Fakültesi, Türk Dili ve Edebiyatı Bölümü, İstanbul, Türkiye

ORCID: T.A. 0000-0002-9945-9393

Sorumlu yazar/Corresponding author: Türkan Alvan,

Fatih Sultan Mehmet Vakıf Üniversitesi, Edebiyat Fakültesi, Türk Dili ve Edebiyatı Bölümü, İstanbul, Türkiye

E-mail: talvan@fsm.edu.tr

Başvuru/Submitted: 21.09.2020

Revizyon Talebi/Revision Requested:

17.11.2020

Son Revizyon/Last Revision Received:

19.11.2020

Kabul/Accepted: 19.11 .2020

Online Yayı/Published Online: 00.00 .0000

\section{Atıf/Citation:}

Alvan, T. (2020). Klasik Türk şiirinde dolab-nâme hakkında mülahazalar. TUDED 60(2), 443-476. https://doi.org/10.26650/TUDED2020-0031

\section{ÖZET}

Eski Çağlardan beri kullanılan su dolapları günümüzde hâlâ mevcuttur. Günümüze on yedi tanesi ulaşsa da Suriye'nin Hama şehri Âsi Nehri üzerine kurulan su dolaplarıyla hala meşhurdur. Türlerine göre su çarklarının yaygın adları na 'ura, dôlâb ve sâkiya'dır. Hama'daki su dolapları içinde en büyüğü olan Dolab-1 Muhammedî h. 763'te (m.1361) yapılmıştır. Dolab-1 Muhammedî’yi Hama hâkimi olan Türk asıllı Aydemir eş-Şeyhî yaptırmıştır. Ancak efsanelerde Dolab-1 Muhammedî’yi yapan marangozun Anadolu'daki ilk Hıristiyanlardan olan Antakyalı Habib-i Neccar olduğu anlatılır. $\mathrm{Bu}$ makalede dolabname türüne ilham veren Dolab-1 Muhammedî efsaneleri ve su dolaplarından bahseden örnek şiirler incelenmiştir. İnler gibi ses çıkararak yavaş yavaş döndügü için su dolabı, klasik Türk şairlerinin vazgeçemediği bir mazmun olmuştur. Bu şiirlerde âşık kendini su dolabı ile özdeşleştirir. Âșı̆ıın sevgiliden ayrı kalışı ile ettiği âhları ve feryatları, su dolabının uzaklardan duyulan iniltisine benzer. Dolabnâme ise, su dolabının dilinden "Allah aşkının terennümünü ifade eden sorulu cevapl manzume" demektir. Bundan başka bu çalışmada dolabname türünün tanımının yetersizliği üzerinde durulmuştur. Âşıłk Yunus'un ve Kaygusuz Abdal'ın dolab-nâme şiirlerinde muhtevasına göre farklılık vardır. Ayrıca klasik Türk şiirinde de dolabnâme özelliğine sahip şiirler vardırr. Dolab-nâme örneklerine sadece Tekke edebiyatı içinde değil; Anonim Halk edebiyatı, Âşık edebiyatı, hatta Dîvân edebiyatı içinde rastlanabilmektedir.

Anahtar Kelimeler: Su dolapları, Habib-i Neccar, Klasik Türk şiiri, Tür, Dolab-name

\section{ABSTRACT}

Waterwheels that have been used since ancient times are still available today. Notably, Hama, Syria, is still famous for its waterwheels built on the Orontes River. Common names for waterwheels are naura, dolab, and sâkiya. The Noria al-Muhammadiyya, constructed in 1361 by Sheikh Aydemir, is the largest waterwheel in Hama. Legends say that its carpenter was Habib-i Neccar from Antakya, one of the first Christians. We examined examples of the legends and poems about waterwheels that inspire a type of cupboard. The waterwheel has become an indispensable classic for Turkish poets because it turns slowly, making sounds similar to crying. In these poems, the lover identifies himself as a waterwheel. The love and the screams of the lover with the feeling of staying apart from their beloved are similar to the groans heard from far away Dolab-nama also means the verse in question from the language of the water closet with the question, "Expressing the chant of love of Allah." Moreover, the insufficient definition of the dolab-nama was emphasized. There are differences between Âşık Yunus and Kaygusuz's dolab-namas. Dolab-namas are found in Sufî literature, anonymous folk literature, minstrel literature, and Divan literature.

Keywords: Waterwheels, Habib-i Neccar, classical Turkish literature, genres, dolabnama 


\section{EXTENDED ABSTRACT}

This work aims to study norias, which are an original type of water construction, and analyze their reflections on classical Turkish literature, founded along the Orontes River. Hama city of Syria is still famous for its waterwheels built on the Âsi River. Common names of waterwheels according to their types are naura, dolab, and sâkiya. The word asiyab (watermill) has been used in different forms with real meanings and reflects the symbols in these sources. Mill was used as a word that denoted the "heart." However, the millstone was used for the characteristics of turning, moaning, grinding, spreading, and weight.

The Noria al-Muhammadiyya is the biggest waterwheel in Hama. However, legends say that the carpenter who designed the Noria al-Muhammadiyya was Habib-i Neccar, one of the first Christians in Anatolia, hailing from Antakya. In this article, examples of the legends of the Noria al-Muhammadiyya and poems about the waterwheel that inspire the type of cupboard are examined. The waterwheel has become an indispensable classic for Turkish poets because it turns slowly, making sounds similar to crying. In these poems, the lover identifies himself as a waterwheel. The love and the screams of the lover with the feeling of staying apart from their beloved are similar to the groans heard from far away. By contrast, Dolab-nama means the verse in question from the language of the waterwheel with the question, "Expressing the chant of the love of Allah." Moreover, the insufficiency of the definition of the type of cabinet was emphasized. There are differences between Âşık Yunus and Qayghusuz Abdal's dolab-namas. Mentions of the Dolab-nama are not only present in Sufĩ literature but also in anonymous folk literature, minstrel literature, and Divan literature.

This study produced the following results:

1. Hama has been known as the city of the waterwheels (Medinetü-Nevâ'ir). Ibn Saîd Mağribî, İbn Battûta, Abdurrahman Hibrî, Evliya Çelebi, and Karacaoğlan, who traveled to Hama, discussed Hama’s waterwheels.

2. Dolab-nama had been written under the inspiration of moans of rotating a tool, called a dolab, which helps to draw water by cutting off a tree in the forest. It expressed in the poem the ephemerality and deceptiveness of the world's blessings and stressed that an essential element for all people is the love of Allah. There is a resemblance to Qayghusuz Abdal's poem in the means of form and content. His poem is an apt sample of the dolab-nama genre, a part of Turkish Sufì literature.

3. The literature has accepted that Âş1k Yunus and Qayghusuz Abdal wrote the first dolab-namas. Since Kaygusuz Abdal's dolab-nama is didactic, it differs from Âşık Yunus's dolab-nama. The woeful waterwheel of Âş1k Yunus is suffering the love of Allah. By contrast, Kaygusuz Abdal's dolab-nama includes ego training. So we divide the dolab-nama genre into two types: a divine love-teller dolab-nama and a judge of selfishness and egoism. Âşıâne Dolab-nama speaks of the love of Allah with an ambitious style. The pioneer of this genre 
is Âş1k Yunus. In this type, there is a relationship between relief and witness and a yearning for Elest Bezmi. The dolab-nama was written in a narrative style, including the riyazât and mujahede, avoiding the pleasures of the world and gaining the love of God. The pioneer of this dolab-nama genre is Qayghusuz Abdal. By contrast, Sheyikh Emir Ahmed Hayâlî-i Gülşenî, who lived in the 16th century, wrote the longest dolab-nama poem (64 couplets).

4) There are some approaches to the definition and qualifications of the dolab-nama. A. Guzel describes dolab-nama as long poems with questions and answers, expressing the chant of the love of Allah. In this definition, the mention of the waterwheel is not observed. Thus, every creature can start to talk in the love of Allah. Dolab-namas require an incident that happened to the poet, a complaint stemming from this incident, and a longing for the past. The main thought in this type of literature is not forgetting the afterlife, the main life, and not being deceived by the charms of daily life. The waterwheel repents its sins crying. We observe that the waterwheel swears off its old and arrogant days. By contrast, divine love is emphasized in dolab-namas in a manner similar to that in Yunus Emre's dolab-namas. However, dolabnamas are not merely a genre that exists in Sufî Literature. Dr. Edip Kızıldağlı (1920-2002), who wrote compositions on the folklore of Antakya, tells of a folk song about girls who work in fields. This folk song is proof that signs of dolab-namas have been observed in Tasavvuf literature, anonymous folk literature, and minstrel literature. 


\section{GÍRİŞ}

Su dolabı Türkçe'de yaygın tabirle “ahşap bir çark ile su çıkarma sistemi” (Özbay, 2012, s. 3) anlamına gelir. Çağlar boyu dünyada yerleşim ve tarım alanlarına göre daha alçakta kalan kaynaktan su çıkarmaya yarayan çarklar, mekanizmalarına göre farklı isimler almıştır. Türlerine göre su çarklarının yaygın adları na 'ura (noria, water-wheel), dôlâb veya sâkiya' dır. Âsi Nehri havzası üzerindeki su çarkları için nâ ûra ve dôlâb yaygın olarak kullanılagelmiştir.

Nâ '̂rra (ناعورة) su üzerinde dönen büyük ahşap çarktır (Özbay, 2012, s. 2-3). Çark dönerken sürtünme ve ahşabın çatırdamasından kaynaklanan inlemeye benzer yüksek ses çıkarır. Arapça'da çoğulu navâ '̂̀r (نواعير) olan nâ 'ûra kelimesi; "feryat etmek; bir şeye acımak" anlamındaki na 'a (نعى) ve "inleme, zangırdama" anlamındaki n ir (نعير) sözcüklerinden türeyen ve "inleyen" anlamına gelen bir sözcüktür. Dönerken inleyerek ses çıkaran nâ '̂̂ra ile Türkçe'deki "narâ atmak" arasında da ilişki olduğu kuvvetle muhtemeldir. Arapça'dan Farsça ve Türkçe’ye geçtiğini düşündügüüüz dôlâb (دولاب) da teknik açıdan nâ 'ûra ile aynı mekanizmadır. Öte yandan Arapça' da "sulamak" fiilinden türeyen "sâkiya" (قويةتساب) ise "sulayıcı alet" anlamında, bostan / beygir dolabı demektir. Sâkiya kuyu gibi durgun su üstünde hayvan gücüyle döndürülen yatay dişlinin dikey dişliyi döndürmesiyle işleyen ahşap bir mekanizmadır. Zincir veya halatla dikey dişliye bağlanan kaplar, art arda suya girip dolar, yukarıya çıkıp ters dönerek suyunu boşaltır. Türkçe'deki dolap beygiri gibi dönmek deyiminde, sâkiya kastedilmektedir.

Su dolabının enerjisiyle dönen taşla, genellikle un öğütmek için kullanılan mekanizmaya ise âsiyâb (آسياب) denir. Su değirmenleri (water-mill), genellikle su dolaplarının yakınında inşa edilmişlerdir. Belki bu yüzden su dolabı ile âsiyâb sıkça karıştırılmaktadır. ${ }^{1}$

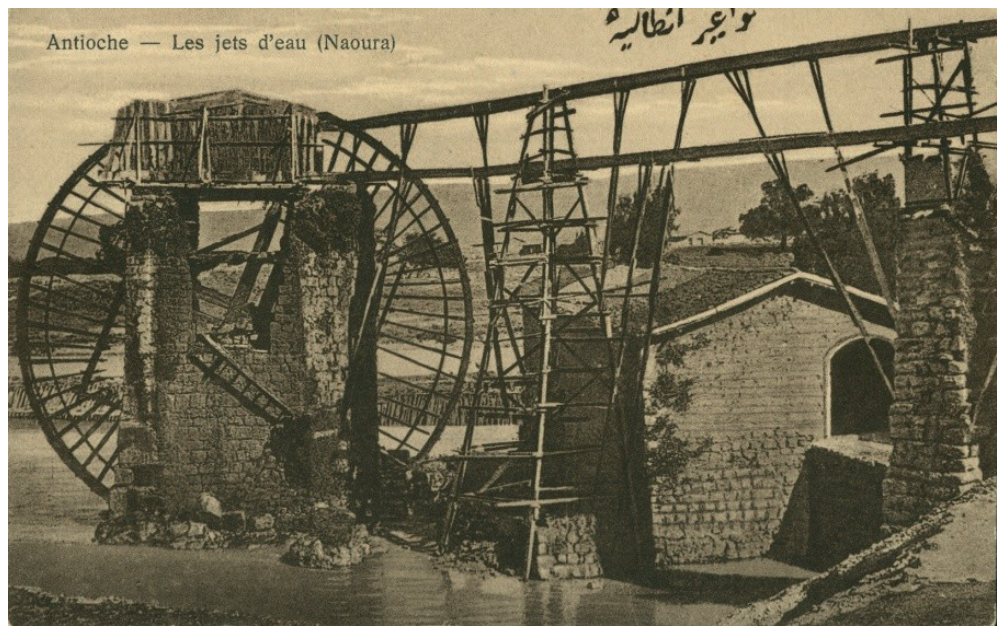

Antakya'da Âsi Nehri üzerinde bir naura ve su değirmeni, 20.yy. başı

(Demir, 1996, s. 189)

1 Meninski nâ ûr kelimesini “su değirmeni” olarak açıklamıştır (Tulum, 2011, s. 1364). Ancak Burhân-1 Katı’ya göre "su değirmeni”" için sadece âsyâ / âsiyâb kullanılmalıdır. (Mütercim Âsım, 2009, s. 26-27) 
M.Ö. 48'de Hirtius, "De Bello Alexandrino" (İskenderiye Savaşı) adlı eserinde su dolaplarından bahsetmiştir. Daha sonra su dolaplarından bahseden pek çok teknik eser yazılmıştır. Ancak M.Ö. 1. yüzyılda Lucretius'un yazdığ1 "De Rerum Naturae” (Evrenin Yapıs1), su dolaplarından bahseden ilk edebi eser kabul edilir. 10. yüzyıldan itibaren birçok tarihçi, coğrafyacı ve seyyahın notlarından Asya'da ve Endülüs bölgesinde su dolaplarının yaygın ve yerleşik bir yapı türü haline geldiği anlaşılmaktadır (Özbay, 2012, s. 21-58). Arap seyyah İbn Battûta Tancî XIV. yüzyılda Hama, Semerkand, Hindistan, Amasya ve Niğde'de gördüğü su dolaplarından bahsetmiştir. XVI. yüzyılda Mimar Sinan da Sâ'î Mustafa Çelebi’ye yazdırdı̆̆ı Tezkiretü'l-Bünyan'da yaptığı su dolabından bahsetmiştir.

Öte yandan Suriye'nin Hama şehri su dolapları, yani nâ ûralarıyla meşhurdur. Bu yüzden Hama, Medinetü'n-Nevâ 'ir (Su dolabı şehri) diye bilinir. Suriye'de, Âsi Nehri (Orontes) üzerindeki Apamea antik kentinde bulunan bir mozaik, V. yüzyıldan beri nâ ûraların kullanıldığını belgelemiştir. Âsi Nehri'ndeki nâ' ûraların görevi, nehir suyunu on altı metre derinlikten alarak yüksekteki su kemerlerine ulaştırmaktır. Bu şekilde nâ ûralar yüzyıllardır, Hama'nın su ihtiyacını karşıladığı gibi çiftçilerin tarlalarını sulayarak yetiştirilen meyve ve sebzelere can suyu olmuştur. Hama'da toplam yüze yakın olduğu söylenen su dolaplarından sadece on yedisi bugüne kadar ayakta kalmayı başarmıştır (Yurdalan, 2006, s. 107-110). Tarihî su dolapları farklı isimlere sahiptir (Noria al-Bisriyya, Noria al-Utmaniyyatani, Noria al-Gisryya, Noria al-Ma'muriyya, Noria al-Ma'ayyadiyya, Noria al-Ga'bariyya Noria al-Gilaniyya, Noria al-Sihyuniyya, Noria al-Hudura, Noria al-Dawalik, Noria al-Dahsa, Noria al-Maqsaf ve Noria al-Muhammadiyya). Günümüzde yalnızca turistik amaçla onarılan ve eski işlevi bulunmayan nâ '̂rraların, Suriye savaşı sebebiyle akıbetleri meçhuldür.

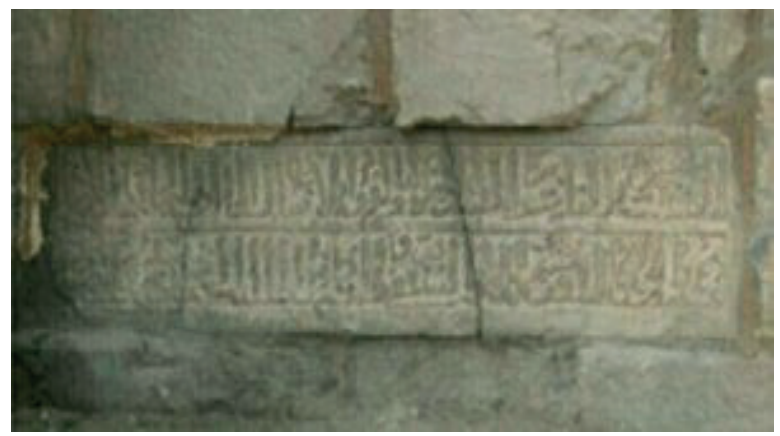

Hama'da Âsi Nehri üzerinde kurulan en büyük su dolabı olan el-Muhammediyye Naurası, “Dolab-1 Muhammedî” adıyla bilinmektedir. Bugün çalışır durumdaki Dolab-1 Muhammedî’ye ait su kemeri üzerindeki Arapça kitabede mealen "Bu büyük ve kutsal naura, efendimiz Aydemir b. Abdullah eş-Şeyhî et-Türkî zamanında, h. 763’te (m.1361-62) Ulu Cami’ye su ulaştırmak için inşa edilmiştir." yazılıdır. Kitabeye göre Dolab-1 Muhammedî'nin kitabesinde bahsedilen Türk, Aydemir eş-Şeyhî' dir. Memlukluların Hama hâkimi olan Aydemir eş-Şeyhî Efendi, Hama'da kendi yaptırdığı türbede medfundur (Özbay, 2012, s. 160-169). 
Evliya Çelebi, Hama ziyaretinde ihtişamına hayran kaldığı Dolab-1 Muhammedî’yi özetle şöyle anlatmıştır:

80 arşın büyüklügüündeki Dolab-1 Muhammedî, Hama'nın en büyük su dolabıdır. Yeri göğü inleterek dönen Dolab-1 Muhammedî’nin sesi sekiz saat mesafedeki çölden bile duyulurmuş; hatta dolabın yanına gidip dinleyenler, iniltinin şiddetinden sağır olurmuş. Dolab-1 Muhammedî’nin tahtaları Ba'lbek Dağları'ndan getirilen çam ağaçlarıymış ve dolabın etrafında binlerce su kovası varmış. Büyük vakıfları olan Dolab-1 Muhammedî’nin hizmetinde muaf ve müsellem 40-50 hizmetli çalışıyormuş. Dolab-1 Muhammedî'nin sayesinde çıkan su, Hama'daki güzel bahçelere hayat veriyormuş. Hama sıbyan mektebi çocukları Dolab-1 Muhammedî’ye sarılıp yukarı çıkar, sonra Âsi Nehri suyuna atlamayı severlermiş. (Evliya Çelebi, 2011, c.I, s. 3/41).

İbn Battûta Seyahat-nâmesi'nde yer alan Hama'daki su dolaplarından bahseden coşkulu şiirlerde dolapların çıkardığı sesten mülhem ağlamak, inlemek tabirleri dikkat çekicidir. Bu şiirlerden birinde nâ 'ûra kelimesi aynı zamanda "sevgili, dilber" anlamına gelmektedir. Büyük sahabelerden Ammâr b. Yâsir'in neslinden gelen ve İbn Sa îd Mağribî diye tanınan Gırnatalı şair Nûreddîn Ebu'l-Hasan Ali Ansî’ye (v.1286) ait bir şiirde ise Âsi Nehri'nin isyankârlı̆̆ ile insanın Hakk'a teslimiyeti, aşk derdiyle ağlaması arasında ilişki kurulmuştur (Tancî, 2004, s. 74-75):

Hak Te'ala himaye etsin Hama'nın çevresini

Durdum, baktım ve dinledim kalbim neşeyle doldu $\ldots$

Âsi bir nehir buradayken nasıl dururum?

Onun gibi isyan etmeden kendimi nasıl bulurum?

Çăglarım su dolabı gibi yanlarından akarım

Bak nasıl inlemekte, nasıl ağlamakta... (İbn Saîd Mağribî)

\section{Menkıbelerde Âsi Nehri ve Dolab-ı Muhammedî}

Lübnan'ın Bekaa Vadisi'nde doğan Âsi Nehri, Suriye'den gelip Antakya (Hatay) Samandağ'da denize dökülmektedir. Âsi Nehri'nin güneyden kuzeye ters yönde akıyor görünmesi, farklı efsanelere ve menkıbelere konu olmuştur (Yıldırım, 2017, s. 77-88). Yine Hama'da Âsi Nehri üzerindeki en büyük su dolabı olan ve XIV. yüzyılda Hama hâkimi Aydemir eş-Şeyhî’nin yaptırdığı görkemli Dolab-1 Muhammedî hakkında efsaneler vardır. Âsi Nehri’nin geçtiği Antakya ve Hama'nın birbirine yakın olması yanında ortak özellikleri sebebiyle, her iki şehrin menkıbe ve efsanelerinde Âsi Nehri, Dolab-1 Muhammedî ve Habîb-i Neccâr arasında bazı etkileşimler olmuştur. İçiçe geçmiş bu efsanelerde anafikir olarak “Allah'a asi olmamak” ve “Hz. Muhammed'i sevmenin önemi” üzerinde durulmuştur. 
Âsi Nehri’nin doğal akışa ters akması yüzünden “Âsi” adını aldığını anlatan menkıbeyi Evliya Çelebi özetle şöyle anlatmıştır:

Peygamberimiz (s.a.v) zamanında Hama susuz bir şehirmiş. Yahudi taifesinden İzâ'îl adlı sihirbaz, bir su dolabı inşa etmiş, ama bu dolabı kuracak nehir yokmuş. Dolabı nasıl döndüreceğini soranlara bu Yahudi - Nil’i çöller içinden akıtacağım ve Hama’ya getirdiğim Nil suyu üzerine su dolabını kuracağım, dermiş. Bir gün yollara düşmüş, Mısır'a varıp Mansure şehrindeki kıyısındaki Nil'den dört şişe su alarak bir efsun okumuş ve Hama’ya geri dönmüş. Nil Nehri'nin bir kısmı, bu Yahudi'nin peşi sıra yerin altından tâ Yafa şehrine gelmiş, sonra Askalan beldelerinden incecik bir yolla, Arz-1 Hasan, Ariş, Taberistan, Filistin, Kefirnâhûn (Sıfet) derken Kıbrıs'a kadar akmış. Suyun bu hareketi sırasında Minye Gölü oluşmuş. Sonra o Yahudi'nin ayağı altında Nil suyu gelirken tâ Gülbin Dağı altında durmuş.

Durumdan haberdar olan Hz. Peygamber, Hz. Ali’ye - Yetiş ey Ali! Sihirle Nil Nehri'ni Arz-ı Mukaddes'ten dışarı çıkarıp Rum diyarını harap etmek istiyorlar! diye emredince Hz. Ali derhal Düldül'e binip yetiştiği Yahudi’yi Gülbin Dağı eteğinde öldürmüş. Sihirbazın koynundaki dördüncü şişe Gülbin Dağı'nda kırılmış, Allah'ın emriyle şişeden yere dökülen Nil suyu, Gülbin kayasından -Yâ Allah! sadasıyla batıya doğru akmaya başlamış. Hz. Ali - Ey Âsi, her nehir Hakk’a yönelip kıbleye doğru akarken sen niçin batıya doğru akarsın? Geri dön, âsi oldun, demiş. Hayy ve Kâdir olan Allah'ın izniyle o vakit, nehir dile gelip - Ey Ali! Allah'ın emriyle bu mahalle gelmişken Humus, Hama ve nice şehri sulayıp Antakya'da Habib-i Neccâr'1 ziyaret edip oradan yine kıbleye doğru akayım, demiş. Hazret-i Ali - Dön, yoksa seni keskin Zülfikâr'ımla iki parça ederim, deyince nehir - Ey Ali, eğer vurursan bir parçamı kan, bir parçamı irin akıtırım. Kıyamete dek Allah'ın kulları benden faydalanamaz, demiş. Bunun üzerine Hazret-i Ali - Senin adın Âsi olsun, insanoğlu senden yarar görsün, suyunu içen hayat bulsun, demiş. Sonra Gülbin Dağ1 eteğinde bu sudan içip abdest almış ve Düldül'ü bu suyla sıvamış. İşte Hz. Ali'nin namaz kıldığı bu yere, hâlen Makâm-ı Ali derlermiş ve öldürdüğü o Yahudi de burada medfunmuş." (Evliya Çelebi, 2011, c.I, s. 3/37-38)

Menkıbe göre; Âsi Nehri'nin ziyaret etmek istediği Habib-i Neccar, Hz. İsa'nın Antakya’ya gönderdiği havarilerinden Şem 'ûn-1 Safâ (Simun Petrus), Pavlus ve Yuhanna sayesinde o yörede ilk iman eden kişidir. Marangoz olan Habîb-i Neccar, cüzzamlı oğluyla halktan uzakta Silpiyus Dağı'nda bir mağarada yaşarken Hz. İsa'nın elçilerinin oğlunu iyileştirmesi üzerine hıristiyan olmuş ve Silpiyus Dağı'ndaki mağarasında uzlete çekilmiş. Evliya Çelebi’ye göre Habib-i Neccar, bir süre Payas Dağı eteklerindeki Sürmeli Yayla'da bir süre halka tebliğde bulunmuş. Hatta onun duası bereketiyle bu bölgede veba hiç görülmezmiş (Evliya Çelebi, 2011, c.I, s. 3/32). O sırada Hz. İsa'nın üç havarisi Antakyalıları imana davet edince halktan tepki almışlar ve tutuklanmışlar. Habib-i Neccar koşarak şehre inmiş ve halka Allah'ın elçilerini öldürmemelerini söylemiş. Halk Habib-i Neccar'dan keramet gösterip Antakya Meliki Bî’atü'l- 
Kassân'ın Hıristiyan olmuşken ölen Yavhîd adlı oğlunu diriltmesini istemiş. Allah'ın izniyle çocuk dirilince Bî'atü'l-Kassân iman etmiş. Ama putperest halk karşı çıkmış ve Habib-i Neccar'1 taşlayarak mağarasına dek kovalamış, sonra başını kesip şehit etmiş. Evliya Çelebi Habib-i Neccar'ın başının yuvarlanarak şehrin içine kadar geldiğini ve buraya tekke/camii yapıldığını söylemiştir. Bu azizin vücudu ise Habib-i Neccar Dağı eteğindeki kilisede medfunmuş. Timur burayı ziyaret ettiğinde azizin cesedini ter ü taze bulmuştur. Evliya Çelebi’ye göre sonradan dirilen şehzade Yavhîd, azizin yakınında medfunmuş.

Çoğu müfessir Yâsîn suresinde anlatılan Ashâbü'l-Karye'nin şehit ettiği "Şehrin bir ucundan koşarak gelen habercinin" Habib-i Neccar olduğunu söylemiştir. Bu yüzden olsa gerek, Müslümanlar arasında çok sevilen Habib-i Neccar'ın -aralarında altı asır olsa daHz. Muhammed'in evsafinı gördüğüne ve ilk iman edenlerden olduğuna dair rivayetler anlatılagelmiştir (Yılmaz, 1998, s. 54,69,70). Günümüzde Hatay’da Habib-i Neccar'ın, Silpiyus Dağı (Habibi Neccar Dağı) eteğindeki mağarası (St. Pierre Kilisesi) ve Şem‘ûn-1 Safâ'nın kabri ile beraber medfun olduğu şehir içindeki türbesinin bulunduğu Habib-i Neccar Camii, ülkemizin inanç turizminin önemli bölgelerindendir.

Evliya Çelebi'ye göre Habib-i Neccar, Antakya Kalesi'ni ve halkının bahçelerini sulayan ilk su dolabını yaptığı için "marangozların ve mimarların piridir” (Evliya Çelebi, 2011, c. I, s. 1/339). Bu inanış, Evliya Çelebi’nin şahsî fikrini değil, yöre halkının görüşünü yansıtmaktadır. Dolayısıyla iki menkıbe birbirini tamamlıyor ve Evliya Çelebi'nin ikinci menkıbesinde geçen Âsi Nehri'nin Habib-i Neccar'1 ziyaret etmek istemesinin nedenini açıklıyor. Nitekim bu konuda, Hatay (Antakya) yöresinde tarlada çalışan kızların karşılıklı söylediği dolab-nâme örneği olan bir türküde, Habib-i Neccar'ın su dolabını yapmasından bahsedilmiştir: (Kızıldağlı, 1943, s. 7)

Ben bir ulu ağaç idim

Ne tatliydim ne aciydım

Ben Allah'a duaciydim

$* * *$

Habib Neccar beni kesti

Her dalım bir yere astı

Yüreğime mihlar bastı

Evliya Çelebi’nin aktardığı menkıbede Âsi Nehri, Habib-i Neccar ve su dolabı ilişkisi, İslam-Türk edebiyatına tesir eden farklı din ve kültürlerin tevhid akidesine aktarılmasının güzel bir örneğidir. Bu menkıbeyi tamamlayan ve kelime-i tevhid akidesinin en güzel temsili olan menkıbe ise Dolab-1 Muhammedî hakkındadır. İlk defa XIV. yüzyılda Kaygusuz Abdal Menakıb-nâmesi'nde bahsedilen bu rivayet özetle şöyledir:

Kaygusuz Abdal, 40 dervişiyle hac vazifesini ifâ ettikten sonra, Anadolu'ya şeyhi Abdal Mûsâ'ya kavuşmak üzere yola çıkar. Şam’da Halid bin Velîd ve Baba 
Amr türbelerini ziyaret ederler. Oradan Hama Kalesi'ne gelirler ve Âsi Nehri kenarına oturup sohbet ederler. Hama Kalesi'ne su çıkaran Dolab-1 Muhammedî’yi gördüler. Dolab-1 Muhammedî'nin öyle feryat ile iniltisi, bir günlük yoldan duyuluyordu. Baba Kaygusuz Sultan bu sese kulak verip hayran kaldı. Dolabın ağlayışına çok şaşırdı, mahcup oldu, gönlü coştu ve Dolab-1 Muhammedî için bir kaside söyledi. Kasideyi işitenler hayret ettiler ve kasidenin birer nüshasını not ettiler. Meğer bir zamanlar, yüksekteki Hama Kalesi'ne Âsi Nehri'nden su çıkarmak isteyen halk, bir Hıristiyan ustaya büyük bir su dolabı yaptırmışlar. Yapılan su dolabı Âsi Nehri üzerine konmuş, fakat dönmemiş. Su dolabının dönmeyişine çok üzülen Hıristiyan usta - Yâ Dolab! İsâ as. hürmetine dön! diye dolaba seslenmiş, ama dolab dönmemiş. Bu sefer - Yâ Dolab! Musa as. hürmetine dön! demiş, dolab yine dönmemiş. Nihayet - Yâ Dolab! Muhammed as. hürmetine dön! deyince dolap, Allah'ın izniyle suda dönmeye başlamış. Bunu gören Hristiyan usta, aşka gelip Müslüman olmuş. Bu yüzden dolaba Dolab-ı Muhammedî adını vermişler. O günden sonra haberi duyan halk, bu dolabı görmeye gelir, dolabın iniltisiyle hayrete düşermiş. (Güzel, 1999, s. 123-127)

Edirneli kadı Abdurrahman Hibrî (1604-1656) de Hama'da gördüğü Dolab-1 Muhammedî' den bahsetmiştir. A. Hibrî 1632 'de yaptığı haccın dönüşünde yazdığı Menâsik-i Mesâlik adlı eserinde bir iki cümleyle yukarıdaki menkıbeyi anlatmıştır. Kaygusuz Abdal'dan hiç bahsetmeyen Hibrî'ye göre de Dolab-1 Muhammedî' nin ustası, iyi niyetli bir Yahudi'ydi (İlgürel, 1975, s. 121). Evliya Çelebi ise 1672'deki hac seyahatinde Hama'da gördüğü Dolab-1 Muhammedî'nin menkıbelerini anlatırken Kaygusuz Abdal'dan bahsetmez. Evliya Çelebi'ye göre Dolab-1 Muhammedî'nin marangozu aziz değil de sihirbaz bir Yahudidir. Âsi Nehri'ni sihirle tersine akıtıp Misır'dan Hama'ya getiren bu sihirbaz Yahudi'yi Hz. Ali öldürünce yaptığg Dolab-ı Muhammedî âtıl kalmıştır. Bu Yahudi’nin oğlu dolabı tamir etmişse de döndürememiş. O zaman sihirbaz Yahudi’nin genç oğlu, Dolab-1 Muhammedî’ye ilk "Hz. Adem'i seversen dön!” demiş, dönmeyince "Bütün peygamberleri seversen dön!" demiş, dolap yine dönmemiş. Ama "Muhammed aşkına dön!" deyince su dolabı dönmeye başlamış. Bu olaydan sonra müslüman olan Yahudi genç, Muhammed Ensarî adını almış, vefat edince de su dolabı civarına defnedilmiş. Evliya Çelebi, "Yâ Muhammed!" diye dönen Dolab-1 Muhammedî’nin sesinin yeri göğü inlettiğini, sekiz saat mesafedeki çölden bile duyulduğunu, hatta dolabın yanına gidenlerin iniltinin şiddetinden sağır olduğunu söylemiştir (Evliya Çelebi, 2011, c.I, s. 3/41).

\section{Su Dolabının Türk Edebiyatına Etkisi}

Arap coğrafyasında dolab, na ura veya sâkiya diye bilinen su çarkları, Türk edebiyatına dolab (tolab) olarak geçmiştir. Dîvân şiirinde sıkça kullanılan âsiyâb ise un vb. öğütmek için daha çok su dolabı sayesinde dönen su değirmeninin adıdır. Büyük su dolaplarının yanında kuruldukları için su dolabı ile su değirmeni bazen şiirlerde karıştırılmaktadır. 
Su dolaplarının Türk edebiyatına iki türlü etkisi olmuştur:

I. Su dolapları klasik Türk şiirinde dolab-nâme türünün ortaya çıkmasını sağlamıştır. Dinî-Tasavvufî Türk edebiyatı nazım türlerinden biri olarak bilinen dolab-nâme, su dolabının dilinden "Allah aşkının terennümünü ifade eden sorulu cevaplı manzume" olarak tarif edilmiştir (Güzel, s. 613). Dolab-nâme türüne ilham veren Hama'da Âsi Nehri üzerindeki Dolab-1 Muhammedî'dir. Bildiğimiz kadarıyla ilk defa Kaygusuz Abdal (XIV-XV.yy.) hac dönüşü 40 dervişiyle Âsi kıyısında otururken seyrettiği ve menkıbesini dinlediği Dolab-1 Muhammedî’ye hayran kalmış ve Dolab Kasidesi'ni söylemiştir. Kaygusuz Abdal'ı örnek alan sonraki şairler ise yazdıkları bu tür şiirlere "dolab-nâme" adını vermeyi tercih etmişlerdir. Mesela Şeyh Ahmed Hayâlî-i Gülşenî’nin (1485-1570) Kaside-i Dolab-nâme'si, Kırım Hanı Gazi Giray'ın (1554-1607) Dolab-nâme'si bu türün örneklerindendir.

II. Dolab ve âsiyâb klasik Türk şairlerinin hayatta çektikleri sıkıntıları anlatırken kullandıkları önemli ve yaygın bir mazmundur. Modern Türk edebiyatında da bu mazmun "aşk uğruna veya dünya dertleriyle çile çekmek" anlamında kullanılmaktadır. Sabahattin Ali'nin bir âsiyâbı anlattı̆̆ı Değirmen öyküsü ile Nezihe Araz'ın Yunus Emre'yi anlatan Dertli Dolap romanı buna örnek verilebilir.

Dolab ve âsiyâb inler gibi ses çıkararak yavaş yavaş döndüğü şekliyle, klasik Türk şairlerinin vazgeçemediği bir mazmundur. Bu şiirlerde âşık kendini su dolabı ile özdeşleştirir. Âşığın sevgiliden ayrı kalışı ile ettiği âhları ve feryatları, su dolabının uzaklardan duyulan iniltisine benzer. Âşı̆̆ın boyu, su dolabı gibi iki büklümdür; gözyaşları dolabı döndürür. Sevgilinin güzellik bahçesindeki çiçekler, ağaçlar âşı̆̆ın gözyaşları ile sulanırken büyürler. Sevgilinin saçları, su dolabına (sâkiya) asılı kovaların ipidir. Vuslat bahçesinin çiçekleri, ağaçları âşı̆̆ın dertli dolabı sayesinde sulanır, yeşerir: 


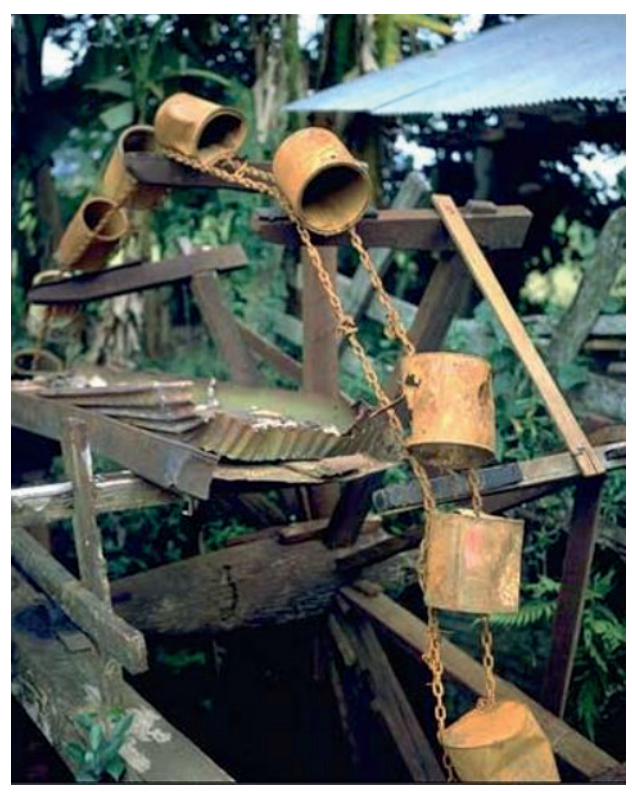

Cümle tolâb-1 cihânı seyr idersin ey nigâr

Gözlerüm yaşı bigi âlemde dolâb olmaya (Ahmed-i Rıdvan Dîvânı, G.714/2)

Adlî gözyaşın akıdup yine tolâb gibi

Gülsitân-1 ser-i kûyun tolanup zâr eyler (Adlî Dîvânı, G.24/9)

Nice bir inlede vü ağlada ey serv-i çemen

Hasret-i gülşen-i kûyun beni tolâb gibi (Necâtî Bey Dîvânı, G.614/2)

İnleyü inleyü bûstân-1 sarâyun dün ü gün

Döne döne sularam eşk ile dolâb gibi (Tacizâde Cafer Dîvânı, G.215/5)

Gözlerim yaş akıdur ben ağlarım dolâb-vâr

Billâh ey serv-i sehî seyr it bu dolâb üstine

Kûze-i yâkûtdan kevser saçardı âfitâb

Reng-i la'lün 'aksi düşse çark-1 dolâb üstine (Ahmed Paşa Dîvânı, k.3/10-11)

Akıdur âb-1 revân her yana çeşmüm kûzeki

İniler bî-çâre dil derd-ile san tolâbdur (Muhibbî Dîvânı, G.1066/3)

Gönül inler gamundan dem-be-dem rûh-1 revân ağlar

Bu bâğun çeşme-sârı hep benüm eşk-i revânumdur (Bâkî Dîvânı, G.128/2) 
Aşağıdaki beyitte, suda aksini gördüğü şimşir ağacını sevgili zanneden su dolaplarından bahsediliyor. Zavallı dolaplar döne döne sevgili zannettikleri sudaki boş yansımaya dert anlatırlar:

Miyân-1 cûyda 'aksin görince şimşâdun

Döker döne döne derdini ana her dolâb (Gelibolulu Âli Dîvânı, k.70/12)

Necâtî Beg'in meşhur “döne döne” redifli gazeline Lâmi'î Çelebi’nin yazdığg nazirede su dolabı yine âşı̆̆ın sembolü olmuştur: (Horata, 1998, s. 59-61)

Girye vü zârî ile oldı Necâtî dolâb

Gül-sitân-ı ser-i kûyunı sular döne döne

Lâmi’̂̂ serv-i kadün yâdına dolâb-sıfat

Gülşen-i kûyunı zâr ile sular döne döne

Şairler feleğin dönüşü ile su dolabının dönüşü arasında bağlantı kurmuşlardır. Su dolabının inleyerek ağır ağır dönüşü gibi, feleğin oyunları âşıkları türlü dertlere düçâr eder, gözyaşları o dolapta dönen sular gibi akar. Âşı̆̆ın âhı yerde kalmaz, su dolabında yükselen su gibi yükseğe çıkar:

İnledürsin döne döne dem-be-dem dôlâb-veş

Yirde kalmaz irer ey gerdûn-1 dûn âhum sana (Zâtî Dîvânı, 1, 23/4)

Aşağıdaki beyitte bu kez felek inleyen bir su dolabı olmuştur. Gökyüzünde çakan şimşekler ise aslında feleğin zamanın acımasızlığı yüzünden ettiği feryatların sesidir:

Figân-1 ra 'd sanman devr elinden

Tolâb-1 çarh iniler zâri zârì (Azîzî Dîvânı, G.384/6)

Aşağıdaki beyitte Bâkî, beygir dolabından (sâkiya) bahsetmiştir. Bâkî’ye belki de Hac yolunda uğradığg Hama'daki su dolapları ilham vermiştir. Beyitte eşek tabiatlı rakip, sevgilinin semtine âşıktan başka herkesi taşırken âşık sevgiliden uzak düşmüştür. Bu yüzden döktüğü gözyaşları sel olan aşığın iki büklüm boyu da su dolabı gibi gözyaşlarını döndürür durur:

Kûyuna gayrıları çekse rakîb-i har-tab"

Seyl-i eşkümle döner kadd-i dü-tâ dolâba (Bâkî Dîvânı, G.436/4) 


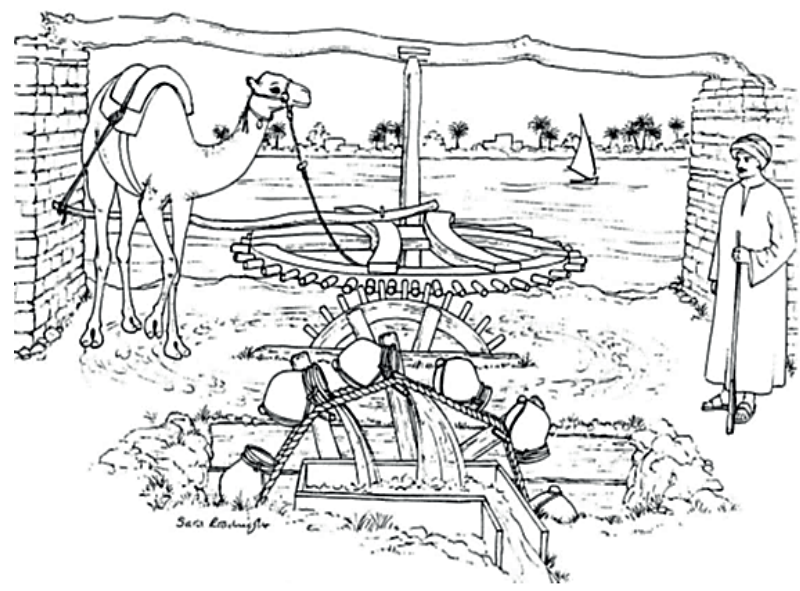

SÂKIYA (BEYGİR DOLABI)

Bâkî ve Şeyhî aşağıdaki beyitlerde hem su dolabını hem su değirmenini (âsiyâb) birlikte kullanmışlardır. Şeyhî’nin Hüsrev ü Şîrîn mesnevisinden alınan dört beyitte dokuz kat feleğin dönüşü su dolabına benzetilmiştir. İnsanoğlunun dünya hayatı, o dolapta dönen su gibi kısa ömürlüdür. Tuhaf olan bu su dolabında dönen su içinde olsa da insanoğlunun kimi susuz, kimi suya kanmıştır; hiçbirinin hâlleri birbirine benzemez. Dünyanın iyi kötü halleri, su değirmeninin buğday öğütmesi gibi insanı un ufak eder. Bu kaderden kaçış yoktur:

Felekler gerdişi tolâba benzer

$\mathrm{Bu}$ halk ol gözelerde âba benzer

Bu tolâb içre halkun bu'l-'acebdür

Kimi sîrâb u kimi teşne-lebdür

Degirmen gibidür ahvâl-i 'âlem

İçinde dâne-i gendümdür âdem

İki taş arasına düşdi dâne

Ögütdi bil anı devr-i zamâne (Şeyhî), (Latîfî, 2000, s. 342-43)

Hevân içre ezel bir sadme urdı sarsar-1 âhum

Döner dolâb-1 çarh ol dem bu demdür âsiyâb-âsâ (Bâkî Dîvânı, G.2/2) 
Dolab kelimesi aşağıdaki iki beyitte "su dolab1, dönme dolap, dolap çevirmek" şekinde hemen bütün anlamlarında birlikte kullanılmıştır. İlk beyitte Bâkî, gökkuşağını (kavs-ı kuzeh), su dolabına benzetmiştir. Beyti iki şekilde açıklayabiliriz. İlk anlamıyla yağmur sonrası çıkan gökkuşağı hüsn-i ta'lil yoluyla, dünyayı sulayan kocaman bir su dolabına benzetilmiştir. Ayrıca kavs-1 kuzeh kelimesi felekten kinayedir. Dolap kurmak, feleğin insana türlü tuzaklar kurması anlamında kullanılmıştır. Şair Zihnî ise hem su dolabını hem de dönme dolabı aynı beyitte kullanmıştır. Beytin ilk mısraında sel gibi gözyaşı akıtan âşı̆̆ı, yine kendini hasretle inleyen su dolabına benzetmiştir. İkinci mısrada şair, ayyüzlü küçük sevgiliyi bayram yerinde dönme dolaplara bindirip döndürürken acaba sevgilinin gönlünü nasıl ederim, diye bir yandan türlü dolaplar çevirmekte, tuzak kurmaktadır:

Dollâb kurd1 kavs-1 kuzeh bâğ-1 'âleme

Mîzâb gibi her yanadan akdı cûy-bâr (Bâkî, Dîvânı k.17/5)

İnleyüp dolâb-veş çıkdı gözümden âblar

Döndürince ol mehi kurdum nice dolâblar(Zihnî), (İ.Beliğ, 1999, s. 85)

Aşağıdaki kıtada Gelibolulu Âlî, kütüphane olarak kullanılan dolap ile su dolabı arasında ilginç bir ilişki kurmuştur. Ona göre kitap dolabı, ilim ve fazilet bahçelerini sulayan su dolabı (sâkiya) gibidir. Her kitap ölümsüzlük suyu ile dolu bu dolaba asılı kovalara benzer. Şair kıtanın sonunda "Felek döndükçe eğitim ve fen bilimlerine ait çiçek bahçelerini sulayan bu dolap hep devretsin, susuz kalmasın." diye dua etmiştir:

Berây-1 Dolâb-1 Kitâb-hâne:

Bostân-1 'ilm ü fazla bu dûlâcdur dolâb

Âb-1 hayât ile tolu delv oldı her kitâb

Şâd-âb idüp riyâz-1 ma 'ârif hadâ' 1 kın

Döndükçe çerh ifâzada olsun ol âb-1 tâb (Gelibolulu Âli Dîvânı, kıta 17)

Âşık edebiyatının büyük şairi Karacaoğlan da Hama, Humus ve Halep'e kadar gitmiştir. Karacaoğlan aşağıdaki şiirinde (Boratav, 1983, s. 25), Hama'nın meşhur su dolaplarından şöyle bahsetmiştir:

Çıktım Kırklar Dağı'n seyrân eyledim

Salınarak gider yolu Hama'nın

Yer urdukça dertli dolap iniler

Burcu burcu kokar gülü Hama'nın 
Karac'oğlan der ki kal benim yurdum

Terk ettim sılayı burada buldum

Güzeli çok diye eğlendim kaldım

Kalem kaşlı güzelleri Hama’nın

\section{Dolab-nâme Türüne Eleştirel Yaklaşımlar}

Klasik Türk şiirinde dolab-nâme türü XIV-XV. yüzyılda ortaya çıkmış görünmektedir. Bildiğimiz kadarıyla dolab-nâme türünün tarifini ilk defa literatüre sokan A. Güzel, Kaygusuz Abdal'ın ve Âşık Yunus'un dertli dolapla söyleştiği şiirlerini dinî-tasavvufî Türk edebiyatı nazım türlerinden saymış ve dolab-nâmeyi "Allah aşkının terennümünü ifade eden sorulu cevaplı manzume" olarak tarif etmiştir (Güzel, 2004, s. 613; Güzel \& Torun, 2003, s. 336). Akademik camiada yaygınlaşan bu tanımın dolab-nâme türünün özelliklerini tam olarak karşılamaması sebebiyle, dolab-nâmenin "efrâdını câmi, ağyârını mâni” bir tanımının yapılması için bazı hususları tartışmaya açmakta fayda görüyoruz.

Öncelikle bu tanımda su dolabı adının geçmemesi dikkat çekicidir. Tanımda dolab kelimesi geçmediğinden, bu türde canlı-cansız başka varlıklarla da "Allah aşkının terennümü” için söyleşilebileceği anlamı çıkar. Ama bu sefer de şairin söyleştiği dolab dışındaki başka bir varlık sözkonusu ise böyle şiirlere dolab-nâme demek pek doğru olmaz. Zaten "Allah aşkının terennümünü” soru cevap yoluyla ifade eden şiirlerde çalgılar gibi başka varlıklar da vardır. Şu hâlde bu tür şiirleri, konuşan varlığa göre adlandırmak çözüm olabilir. Yani dolab konuşuyorsa dolab-nâme, çalgı konuşuyorsa çeng-nâme denebilir. Ancak özelde konuşan her varlığı kapsayan genel bir tür adının terim olarak geliştirilmesine ihtiyaç vardır. Belki bu geniş tür adı uşşâk-nâme olabilir. Nitekim Ahmed-i Dâ'î'nin Çeng-nâme diye bilinen mesnevisi, dolab-nâme özelliklerine sahiptir ve Ahmed-i Dâ'î bu şiirine Çengnâme değil, Uş̧̧âk-nâme adını vermiştir. Yine Pir Sultan Abdal aşağıdaki şiirinde tanburu ile söyleşmektedir (Öztelli, 1989, s. 286-287):

Gel benim sarı tamburam

Sen ne için inilersin

İçim oyuk derdim büyük

Ben anun-çün inilerim ...

Koluma taktılar perde

Uğrattılar binbir derde

Kim konar kim göçer burda?

Ben anun-çün inilerim (Pir Sultan Abdal) 
Şairlerin teşhis ve intak ${ }^{2}$ yoluyla her hayvan veya eşyayla söyleştiği şiiri dolab-nâme sayamayacağımıza göre, dolab-nâme denen türün sınırlarını çizmek gerekir. Bu tür şiirlerde şair, canlı cansız her şeyle dertleşebilir. Konuşan varlığın başına bir kaza gelmesi ve âh edip inleyerek geçmişe özlem duyması şarttır. Dolab-nâmenin ana düşüncesi, dünyanın sunduğu güzelliklere insanın aldanmaması, asıl vatanı olan ahireti unutmamasıdır. Şiirde konuşan dolab geçmişe özlem duyarken eski mutlu günlerindeki kayıtsız, gururlu hâlinden dolayı tevbe eder. Bu yönüyle dolab-nâme pend-nâme türüyle yakınlaşmaktadır. Öte yandan dolab-nâmelerde Âşık Yunus'unki gibi tasavvuftaki Elest Bezmi mazmunundan ve Allah aşkından bahsedilmektedir. Yine teşhis edilen varlığın inleyerek başına gelenleri anlatması, dolab-nâmeyi sergüzeşt-nâme türüyle de yakınlaştırır. Genel anlamda uşşâk-nâme diyebileceğimiz bu tür şiirlere şu tanımı önerebiliriz: “Şairin sorusu üzerine teşhis edilen varlığın verdiği cevaplarda Elest Bezmi'nden ayrılık hasretiyle Allah aşkını, sabır ve tevbe ile kadere teslimiyeti tahkiyevî üslupla anlatan şiirlerdir. Teşhis edilen varlığın adına göre isimlendirilebilir.” Dolab-nâmenin tür özelliklerini şemada şöyle gösterebiliriz:

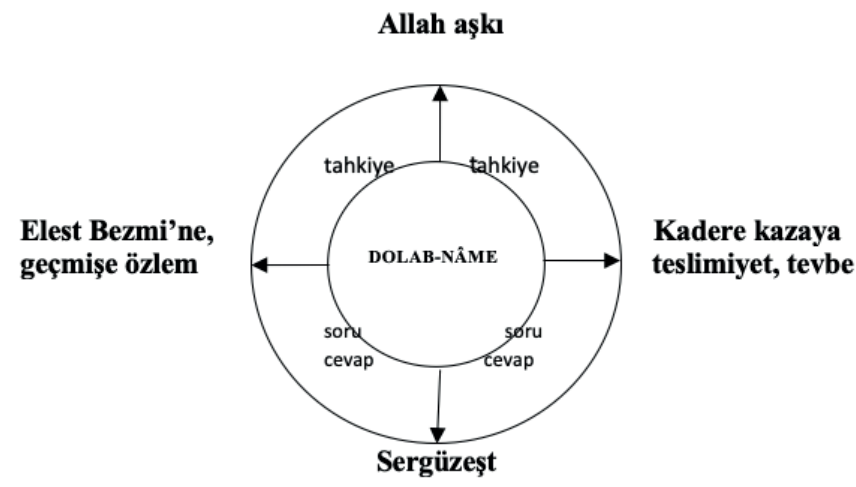

Öte yandan dinî-tasavvufî halk şiiri nazım türlerinden sayılan dolab-nâmenin ilk örneklerini XIV. asır sonu ve XV. asrın başında Âşık Yunus ile Kaygusuz Abdal'ın söylediği kabul edilir. Ancak araştırmamıza göre Âşık Yunus ve Kaygusuz Abdal'dan önce de dolab-nâme türü şiirler vardı. Nitekim yukarıda İbn Battuta su dolabından bahseden şarkı ve şiirlere seyahatnâmesinde yer vermiştir. Âsi Nehri'nin geçtiği bölgelerde uluslararası çapta yapılacak folklorik derlemelerde benzer şiirlerin bulunacağı muhakkaktır. Araştırmamızda dolab-nâme türüne giren bir türküye rastladık. Hatay yöresinden ve tarlada çalışan kızların söylediği bu türküde yukarıda menkıbesini aktardığımız, su dolabının mucidi sayılan Habîb-i Neccar'dan bahsedilmektedir. Süheyl Ünver'in talebesi olan ve memleketi Antakya folkloruna dair derlemeleri olan Dr. Edip Kızıldağlı (1920-2002); tarlada çalışan kızların sırayla, karşılıklı söyledikleri bu türküyü şöyle aktarmıştır:

2 Hayvanlara, eşyaya insanî özellikler yüklemek teşhîs, bunları konuşturmak intâktır. Teşhîs sanat olarak Talim-i Edebiyat'tan önceki belâgat kitaplarında yer almaz. 


\section{Dolap:}

Ben bir ulu ağaç idim

Ne tatllydim ne actydim

Ben Allah'a duacrydim
Kizlar hep beraber:

Dolap niçin inilersin

Eski derdi yenilersin

Murada ermek dilersin

Huи Huи Mevlam Huи!

\section{Kuzlar hep beraber:}

Yalvar ol Hâlik'a yalvar

Yalvar ol Sultan'a yalvar

\section{Dolap:}

\section{Habib Neccar beni kesti}

Her dalım bir yere astı

Yüreğime mihlar bastı

Huи huu Mevlam huu!

\section{Kizlar hep beraber:}

Nehir susuz olur mu ya dolabım?

Dibi kumsuz olur mu aman aman

Ben hekime danıştım ya dolabım,

Kızlar yârsız olur mu halim yaman

Bu türkü, aynı zamanda ezber bozarak dolab-nâme türünün sadece "dinî-tasavvufî / tekke edebiyatı" içinde değerlendirilemeyeceğini, "anonim halk edebiyatı" ve "âşı edebiyatı" içinde de görülebileceğini gösteren bir örnektir. İleride vereceğimiz örnekler de biçim, ahenk unsurları ve muhteva bakımından klasik Türk şiirinin bir bütün olduğunu; bağımsız biçimde Halk şiiri, Dîvân şiiri gibi ayrı değerlendirilemeyeceğini, yani klasik Türk edebiyatının sınıflandırılmasındaki kıstasları da tartışmaya açmaktadır.

Kaygusuz Abdal'dan (h.742-h.845? / m.1342-1444?), az önce yaşadığı bilinen Bursalı Âşık Yunus'un (h.638-843 / m.1240-1438) ilahisi, en meşhur ve en yaygın dolab-nâmedir. Bu ilahi 8'li hece ölçüsü ile yazılmıştır. Âşık Yunus'un Dolab-nâmesi'nin en önemli özelliği Allah aşkı ile dönmesidir. Dolap Kaygusuz'unki gibi geçmişe özlem duymaz, onun derdi sevincidir. Bu yüzden olsa gerek, Emir Sultan'ın dervişi olan Âşık Yunus'un Dolab-nâme'si çok sevilmiş; Asya'dan Balkanlar'a kadar Osmanlı'nın hüküm sürdüğü bütün tekkelerde yüzyıllardır okunagelmiştir. Âşık Yunus'un Dolab-nâme'sinin altı bestesi vardır; bunlar özellikle Halvetî ve Kâdirî tekkelerinde devrân ve kıyam zikirlerinde ilahi olarak okunmaktadır. ${ }^{3}$ Alevîler arasında ise bu eser türkü formunda okunur. ${ }^{4}$ Şu halde Âşık Yunus'un Dolab-nâme'si hem türkü, hem ilahi formuna dahildir (Bkz. Ek 1).

3 “Dolap Niçin İnilersin” Anonim Hüseynî Sofyan İlâhî; Anonim Hüseynî Düyek İlâhî; Anonim Uşşak İlahi; Anonim Nevâ Sofyan İlâhî; Abdullah Dede Rast Devrihindî İlâhî; Selahaddin Gürer Segâh Curcuna İlâhî, Uşşak Sofyan İlâhî.

4 “Benim Adım Dertli Dolap” N.Tüfekçi-Y.Paşmakçı Hüseynî Sofyan Türkü; Müslüm Sümbül Hüseyni İlâhî. 
Kaygusuz Abdal olarak bilinen Alaaddîn-i Gaybî’nin Dolab Kasidesi (Bkz. Ek 2), en uzun şekliyle Kaygusuz Abdal Menakıb-nâmesi'nde bulunur. Kaygusuz Abdal Dîvânı 'nda da yer alan Dolab Kasidesi'ne müstakil olarak bazı mecmualarda da rastlanır. 38 beyitten müteşekkil olan bu kasidede Kaygusuz'un dolaba hitabını içeren soru kısmı 11 beyittir. Dolabın Kaygusuz'a cevabını içeren kısmı ise 27 beyittir. Dolab Kasidesi'nin vezni (mefâ '̂lün / mefâ '̂̂lün / fe 'ûlün)'dür; eserde soru ve cevap kısmının kafiyeleri farklıdır. Sade bir dille yazılan eserde kafiyelerin çoğu da Türkçe' dir. Hakimâne bir üslupla yazılan ve yukarıda menkıbesini verdiğimiz Kaygusuz Abdal'ın dolab-nâmesinin muhtevası özetle şöyledir:

Hac dönüşü, Hama'da Âsi Nehri kıyısına 40 dervişi ile gelip oturan Kaygusuz Abdal kaleye su çıkaran Dolab-ı Muhammedî’nin iniltisini fark eder. Su dolabına niçin dönüp dönüp suya yüz sürdüğünü, niye bağrının delik delik olduğunu, gözyaşı döktüğünü sorar. Feleğin dolabı nasıl bu hale soktuğunu merak etmektedir. Dolap bu soruya cevaben sergüzeştini anlatır. Eskiden yüce bir dağda upuzun gürbüz bir ağaçken kuşlar, çiçekler içinde çok mutludur. Derken kaderin cilvesi, kesilir ve su dolabı haline getirilişini bir bir anlatır. Hz. Zekeriyya gibi kolu başı kesilmiş, Hz. Eyyüb gibi bağrını kurtlar yemiştir. Sonra su dolabı olup gece gündüz döner durur. Bu dünya kimseyi sonsuza dek mutlu bırakmaz. Hz. Süleyman, İskender, Rüstem, Hüsrev, Sam gibi peygamber veya kral kimse ölümden kaçamamıştır. O halde Allah'a dayanmalı, tevekkül edip sabır seccadesinde ömür geçirmelidir.

Kaygusuz Abdal Menakıb-nâmesi'nde bahsedildiğine göre Şeyh Kaygusuz Abdal bu olaydan sonra kendine ilham olan dolab-nâmeyi okuduktan sonra, çevresindekiler şiiri çok beğenmiş ve çoğalttıkları birer nüshasını yanlarına almışlar. Menkıbede bu durum “...Çünkim Kaygusuz Baba Sultan ol tolab üzerine bu kasideyi söyledi, tamam eyledi. İşitdiler, ta 'accub kıldılar ve her biri bir nüshasın aldılar..." (Güzel, 1999, s. 127) şeklinde aktarılmıştır.

Kaygusuz Abdal'ın dolab-nâmesi Kaygusuz Abdal Menakıb-nâmesi'nde, “Kasîde-i Tolâb min-kelâm-ı Kaygusuz Baba Sultân kaddesa'llâh” ve "Cevâb-dâden-i Tolâb Baba Kaygusuz Sultân" ismiyle yer almıştır. Kaygusuz'un bu şiirinden bahseden araştırmacılar şiirin başında yazmadığg halde, "Dolab-nâme" ismini tercih etmişlerdir. Gönül A. Tekin ise "Kaside-i Dolâb" ismini tercih etmiştir (Tekin, 2007, s. 494). Kendisi dolab-nâme adını kullanmasa da klasik Türk şiirinde çoğu şair üslup, vezin, biçim ve kısmen muhteva olarak Kaygusuz Abdal'ın Dolab Kasidesi'ni örnek almıştır. Sonraki dolab-nâmelerin çoğunun Kaygusuz Abdal'a nazîre olarak yazıldığı söylenebilir.

Kaygusuz'unki de Âşık Yunus'unki de tasavvuf düşüncesini yansıtan ve tahkiyeli, sorucevap tekniğiyle yazılan dolab-nâmelerdir. Ancak Kaygusuz Abdal'ın dönen dolabının, Âşık Yunus'un Allah aşkıyla inleyip dönen Dertli Dolab'ının muhtevasına göre farklılaştığı göze çarpmaktadır. Buna göre muhteva olarak dolab-nâme türünü şöyle ikiye ayırabiliriz:

a. Âşıkâne Dolab-nâme: Allah aşkının verdiği derdi yansıtan, Allah’a kavuşma iştiyakını âşıkâne bir üslupla anlatan dolab-nâmedir. Bunun öncüsü Âşık Yunus’tur. Bu üslupta yazılan dolab-nâmede kesret-vahdet ilişkisi ve Elest 
Bezmi'ne özlem vardır. Temsilî istiare ile seçilen varlık, (genellikle dolap) Cenâb-1 Hakk'a ve Hz. Muhammed'e özlem duyan, günahlarına tevbe edip gözyaşları içinde inleyen âşı dervişin sembolüdür. Her derviş insan-1 kâmile bel bağlayıp nefs terbiyesi görür. Fani dünyada çekilen dertler, imtihandır. Ama aşk derdi hepsinden üstündür, aşksız insan kuru ağaç gibi işe yaramaz. Nitekim Âşık Yunus'tan bir asır önce Yunus Emre de aşksız insanı kuru ağaca benzetmiştir:

Âşıklarun yüzinden bellüdür benizinden

Her kim 'âşık olmadı benzer kurı ağaca

Kur'ağacı n'iderler kesüp oda yakarlar

Her kim âş1k olmadı benzer kuru ağaca (Yunus Emre Dîvânı, G.342/5,6)

Dervîş olan bel bağlaya tolaplayın çok ağlaya

Her kande tolap var-1sa anda bâg u bostân olur (Yunus Emre Dîvânı, G.97/2)

b. Hakîmâne Dolâb-nâme: Hikemî bir üslupta yazılan dolab-nâmede, temsilî istiare ile seçilen varlık, (genellikle dolap) riyazât ve mücahede yoluyla nefsini terbiyeye gayret eden dervişin sembolüdür. Fani dünyaya aldanmadan beka yurdu olan ahireti ve Allah rızasını kazanmayı ögütler. Hakîmâne dolab-nâmede de Allah'a dönme çabası vardır. İnsan ancak günahlarına tevbe edip dünya mihnetine sabrederse asıl yurdu olan cennete erişebilir. Hikmetli bir söylemle pendnâme gibi yazılan bu dolab-nâmenin öncüsü Kaygusuz Abdal'dır. Dolabın dönmesi, nefs terbiyesinin sembolüdür, şair dolabın hali ile kendisi arasında irtibat kurar:

Tolabı görüb ben kendü halümi anladum

Bildüm ki Kâdîr kudret birle neler ider (Güzel, 2000, G.58/7)

Dolab-nâme türüne halk şiirinde çok örnek vardır. Mesela XVI. yüzyılda Pir Sultan Abdal'ın Hz. Ali için söylediği dolab-nâme Alevî kültüründe çok sevilmiştir. Ehl-i Beyt-i Mustafa aşkını anlattığ 1 için âşıâne dolab-nâme grubuna giren bu ezgide su dolabının kesilmesi, su çekmesi ile Kerbela'da Hz. Hüseyin ve Ehl-i Beyt-i Mustafa'nın çektiği eziyetler anlatılmaktadır. (Bkz. Ek 5) 


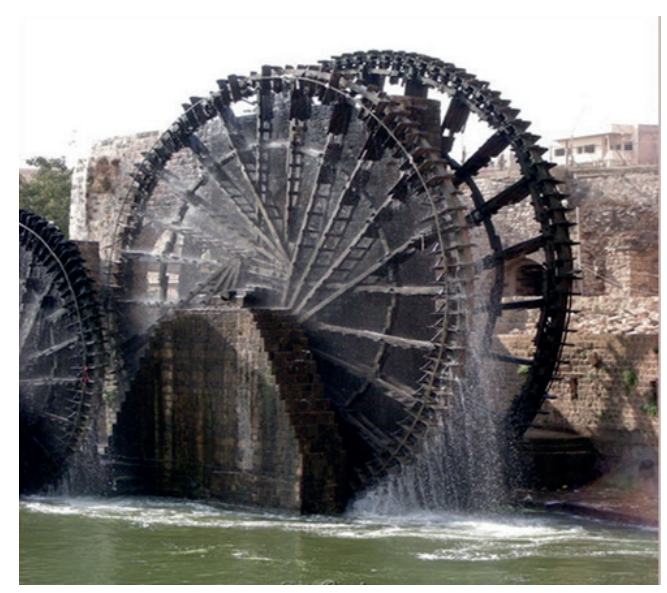

XVI. yüzyılda da yaşayan Şeyh Emir Ahmed Hayâlî-i Gülşenî’nin 64 beyitle yazdığı Dolabnâme ise bu türün bilinen en uzun örneğidir (Bkz. EK 3). Hakîmâne dolab-nâme türüne giren bu şiirin başlığı Kasîde-i Tolâb-nâme 'dir. Âzerî şivesi özellikleri gösteren eser, sade bir Türkçe ile yazılmıştır. Bu şiir Kaygusuz Abdal'ın Dolab-nâme'siyle dil, üslup, şekil, vezin ve muhteva bakımından aynıdır, yani muhtemelen ona nazîredir. İkisi arasında tahkiyevî bir üslupla dolap yapılan ağacın eziyetle dolap oluşu, Allah'a teslimiyet, kazaya rıza göstermek konusunda benzerlik çoktur. Kaygusuz Abdal sadece dünyanın fâniliğini vurgularken Hayâlî-i Gülşenî; katledilen Hz. Yahya ve Hz. Zekeriyya ile Hz. Âdem, Hz. Nûh, Hz. İdrîs, Hz. İbrahim, Hz. Yakub, Hz. İsmail, Hz. İshak, Hz. Dâvud, Hz. Süleyman, Hz. Musa, Hz. İsa ve Hz. Muhammed'in çektiği çileler gibi daha çok örnek gösterir. Pend-nâme tarzında öğüt verir. Bu dolap, nefsin arzusuna uymuştur, gururlu bir ağaçken Allah'a isyanı karşısında yaşadığı pişmanlığı anlatır. Şeyh Ahmed Hayâlî-i Gülşenî’nin Dîvân 'ındaki tek kaside olan Kasîde-i Tolâb-nâme, bir su dolabının yapımıyla ilgili sürecin tamamını naklettiği için belge niteliğindedir.

Dolab-nâme türü, şairin gerçek hayatında yaşadığı talihsizlikleri, geçmişteki mesut günlerin özlemini sembolik olarak anlatıyorsa bir çeşit sergüzeşt-nâme olarak da değerlendirilebilir, demiştik. Buna göre Şeyh Ahmed Hayâlî-i Gülşenî’nin Kasîde-i Tolâb-nâme’si sergüzeşt türüne de girer. Çünkü Şeyh Ahmed Hayâlî-i Gülşenî, hayatının belli dönemlerinde zorluklar yaşamıştır. Bundan başka, bazı araştırmacılar, Kaygusuz Abdal'ın dolab-nâmesi için "bir ağacın sergüzeşti” tabirini kullanmışlardır (Fahri Z., 1927, s. 7-8; Rıza Nour, 1935, 86-803). Diğer bir tespitte ise “Dolabın bu sergüzeşti, Kaygusuz'un da sergüzeştidir. Zira o da yüce bir makamda, bir beyzâde olarak, maiyetindeki adamlarıyla (dalı ve budaklarıyla) yaşarken takdir gereği beyzâdeliğini terk etmiş, Abdal Mûsâ'ya mürid olmuştur.” denilmiştir (Sever, 2013, s. 62). Ancak dolab-nâme türünde şairin asıl vurguladığı geçmişe özlemdir, başına gelen kötü olaylarda bile isyan edilmez, dünyanın faniliği anlatılır. Şu halde Kaygusuz Abdal'ın dervişlikten önceki nefs-i emmaresine köle olduğu beyzâde hayatını özlediğini düşünmek oldukça hatalı bir tespittir. Zira Kaygusuz Abdal Alaiyye beyzâde iken yaşadığı müreffeh hayat1, isteyerek dervişlik uğruna terk etmiştir. 
Sergüzeşt-nâme özelliğine de sahip olarak bu türün en güzel örneği, Kırım Hanı Gazi Giray'ın (1554-1607) yazdığı Dolab-nâme'dir. Mesnevi nazım şekliyle yazılan bu Dolabnâme, 41 beyitten müteşekkildir (Bkz. EK 4). Sade bir Türkçe ile yazılan bu dolab-nâmenin vezni, Kaygusuz Abdal'ınki gibi (mefâ ' îlün / mefâ 'îlün / fe 'ûlün)'dür. Dolab-nâme, Gazi Giray Han'ın gerçek hayatından esinlenerek yazdığı, alegorik bir eserdir. Oldukça iyi bir eğitim alan ve Osmanlı sultanlarının iltifatlarına nail olan Gazi Giray II, Safevi ordusuna karşı savaşırken esir düşmüş ve Alamut Kalesi'ne hapsedilmişti. Burada boynu, elleri zincirli esaret günleri geçirdi. ${ }^{5}$ Bu yüzden Dolab-nâme' deki ağacın kesilip zincirlere vurulması, eski mesut günlerini özlemesi vb. Gazi Giray’ın bu esaret günlerindeki psikolojisini ve başından geçenleri temsilî olarak anlatıyor görünmektedir. Eserin şairin Dîvânçe'sinde ve diğer eserlerde dört nüshası vardır (Abduvaliyeva, 2011, s. 44).

\section{Ahmed-i Dâî’nin Çeng-nâmesi Dolab-nâme Midir?}

Âşık Yunus'un ve Kaygusuz Abdal'ın çağdaşı olan Ahmed-i Dâî'nin h.808 / m.1406'da Emir Süleyman adına yazdığı ve sonradan Çeng-nâme adıyla bilinen eseri üslup, vezin ve muhteva olarak âşıkâne dolab-nâme özelliklerine sahip bir mesnevidir.

Kaygusuz Abdal'ın Dolab Kasidesi gibi mefâ' îlün / mefâ '̂̂lün / fe '̂ulün vezninde yazılan Çeng-nâme 1446 beyitten oluşur. Eserde şair sorar, çeng ve onun parçaları sergüzeştlerini teşhis ve intak yoluyla anlatırlar. Çeng-nâme'nin teması Âşık Yunus’unki gibi Allah aşkıdır. Elest Bezmi'ne özlemden bahseder. Allah'a vuslata tevhid ile ulaşılabileceği anlatılır (vahdetkesret). Mürettep bir mesnevi olan Çeng-nâme'de tevhid, münacat, na't, Çâr Yâr-1 Güzîn olan Hulefâ-i Râşidîn'e medhiye, Emir Süleyman'a medhiye, Vezir Mehmed Paşa'ya medhiyeden sonra "Du 'a-i Hüdavendigâr” başlığında, tekrar Emir Süleyman övülmüştür. Eserin sebeb-i telif kısmında, Sa' dî-i Şirazî’nin -bugün kaybolan- 70 beyitli Çeng-nâme mesnevisini, kendi eserinde özgün katkılarla Türkçe’ye çevirdiğini söyleyen Ahmed-i Dâî, burada poetikasını da anlatmıştır.

Çeng-nâme'nin ilk sekiz bölümünden sonra, "Bahariyye"; "Ser-Âgâz-1 Dâstân” kısmı gelir. Şair dinlediği çengi tasvir eder. Çengin 24 ibrişim kılında yüzbin dili vardır, Ağaçtan gövdesine, ipek kıllar takılmış, deriden yakı yakılmıştır. Perdeleri at kılındandır. Sonra çengin ağzından Emir Süleyman'ın bezmini öven terci-i bend şeklinde bir sâk̂̀-nâme gelir. Burada kimini güldüren kimini ağlatan çeng şairin dikkatini çeker. Asıl hikâye bundan sonra başlar.

5 Kırım Hanı Devlet Giray’ın oğlu olan Gazi Giray II, Sultan III. Murad devrinde I. Şemahi Muharebesi’nde (1578), Osmanlılarla birlikte savaşmıştır. Şirvan’1 ele geçiren Osmanlılar, Safevi ordusunu bozguna uğrattı. Bundan sonra Özdemiroğlu Osman Paşa ile Safevilere karşı büyük başarılar kazanan Gazi Giray, daha sonra Şirvan'1 zapt etmek isteyen Safevi ordusuna karşı savaşırken 1580'de esir düştü. Önce Gence'de, sonra Alamut Kalesi'nde Âsâfî Dal Mehmed Çelebi ile hapsedildi. Âsâfî Dal Mehmed Çelebi'nin Şecâatnâme adlı eserinde bu savaşta ve sonrasında kader arkadaşı olan Gazi Giray’a geniş yer vermiştir. Eserde 7 minyatür Gazi Giray’1 gösterir. Âsâfî Dal Mehmed Çelebi eserinde Alamut'ta gâh kuyuda gâh türlü işkencelere maruz kalışını ayrıntılı olarak anlatmıştır. 1585'te Tebriz'den kaçmayı başaran ikili, Van'da Osmanlı ordusuna katıldılar. Tebriz'in fethi'nden sonra vefat eden Özdemiroğlu Osman Paşa'dan sonra Gazi Giray Yanbolu'da sakin bir hayat sürdü ve III. Murad tarafından 1588 'de Kırım Hanı ilan edildi. Sonraki hayatı da sürekli savaş ortamında geçen Gazi Giray Han büyük zaferler kazanmıştır. 
Âşıkâne dolab-nâme olduğunu düşündügümüz bu kısımda şair, hoş nağmeli çengin neşeli mi, dertli mi olduğunu anlayamaz ve "Su'âl-kerden-i Dâî be-Çeng" (b. 724-764) başlıklı şiirle çenge seslenir ve özetle "Ey sırdaş olan hoş sesli saz! Seni kim terbiye etti; sana bu kuş dilini kim öğretti? Aslın nedir, vatanın nerdedir? Bir başın, yüzbin dilin var. Esirsin, ama özgürsün. Hem dilenci hem şehzade gibisin. Gençsin ama ihtiyar gibi iki büklümsün. İlim irfan, sevgiliden dem vurursun, ama niye dertlisin?” diyen şair, sırrına eremediği bu tezadların açıklanması için çenge yalvarır:

Bu âh u nâle vü zârı nedendür

Bu feryâd ü figân bâri nedendür

Dilün efsûn okur sihrün mü'essir

Bilürven sende vardur bir aceb sir

Beyân it vasf-1 hâlün derd-i dilden

Gönülden râz açılmaz illâ dilden (b.745, 757,764)

"Cevab daden-i Çeng" başlıklı şiirde (b. 765-894), "Benim derdüm ki sı̆̆maz vasfa şerhe" (b. 874) diyen çeng, Ahmed-i Dâî’nin sorularına cevaplar verir. Çeng dört iklimden gelmiş, "dört dostum" dediği ipek teller, selvi ağacı, ceylan derisi, at kuyruğunun yek-vücut olması sayesinde vücut bulmuştur. Çengin bu parçaları, birbirinden ayrı düşünülemez. Ama her birinin birleştikleri andan önce eziyetli sergüzeştleri olmuştur. Ahmed-i Dâî bu sefer çengin her parçasına hitap eden sorular sorar, sergüzeştlerini anlatmalarını ister (b. 895-921). Sonra çengin parçaları olan ipek teller (b. 922-1055), servi ağacı (b. 1056-1150), ceylan derisi (b. 1152-1225), at kılları (b. 1227-1375) ayrı ayrı nasıl oluştuklarını ve başlarından geçenleri ayrıntılı bir şekilde Ahmed-i Dâî̀ye anlatırlar. Sonra "Hatîmetü'l-Kitâb" bölümü öğütler, eser bilgileri, sultana övgü beyitlerinden sonra, dua (b. 1416-1424), münâcât (b. 1425-1446) ile eser sona erer.

İncelememize göre, Çeng-nâme'nin soru-cevaplı kısmı, üslup ve muhteva olarak tamamen “âşıkane dolab-nâme” özelliğine sahiptir. Âşık Yunus "Ben Mevlâ'ya âşık oldum / Anun için inilerem" diye dertli dolabın derdini îcâz yoluyla anlatmıştır. Ahmed-i Dâî ise Âşsk Yunus'un bu mısralarını Çeng-nâme mesnevisinde adeta şerh etmiştir. Çengin her parçası ayrı ayrı sergüzeştlerini anlatırlar, ama hepsinin derdi birdir. Çengin parçalarının sergüzeştini öğrendikten sonra şair, sonunda yazdığı Çeng-nâme’yi bir "Uşşâk-nâme” diye tanımlamıştır (b. 1376). Eşyanın varoluş sırrı aşk-1 ilahîdir. "Vatan maksûd-1 dildür" (b. 1355). Yaratılmadan evvel, Elest Bezmi'nde Allah'la bir olan insan, O’na verdiği özü unutmamalı, dünyanın faniliğini anlamalıdır. Dünya gurbettir, insanı asıl yurdundan koparmıştır. Bu yüzden eserde çengin her parçası "Garîbüz hep cüdâ düşdük vatandan" (b. 1346) der. İnsan-1 kâmili simgeleyen çengin her parçası aşk acısı çeker; Allah’tan ayrı düşmenin derdiyle inler: 
Kişi kim ayrulur kendü ilünden

Gidermez zikrüni dâim dilünden

İnilerüz dökerüz kanlu yaşlar

Ururuz taşa başlar başa taşlar

$\mathrm{Bu}$ derdün şerbetünden esrüdük biz

Çekerüz aşk ile esrükle yük biz (b. 1329, 1330, 1338)

Çeng-nâme’yi Türk edebiyatına kazandıran Gönül A. Tekin, "Su'âl-kerden-i Dâî beÇeng" başlıklı "şair ile çengin soru-cevap şeklinde süregiden konuşmalarının yer aldığ 1 ikinci kısımda, esere münazara üslubu hâkim olur.” demiştir (Tekin, 1992, s. 84). Ancak Çeng-nâme'de münazara üslubu yoktur. Çünkü Sümerlerden itibaren var olan "münazara bilimsel, özellikle de teolojik ve fıkhî tartışmaların yanı sıra iki veya daha fazla canlı ya da cansız varlıkların üstünlük mücadelesine dayanan edebî bir tür olarak da tanımlanmıştır (Wagner, 1993, s. 565-566). Münazaraların ortak teması genellikle zıt özellikteki iki varlığın "üstünlük mücadelesidir."

Aslında bu tanıma birebir uyan ve gerçek bir münazara türünün örneği olan, Çağatay edebiyatı şairlerinden XIV. asır sonu XV. asır başında yaşayan Ahmedı̂’nin Münazara (Telli Sazlar Atışması) adlı eseridir. Ahmedî’nin 130 beyitlik bu küçük mesnevisinde, meyhanedeki sekiz telli sazın her birinin kendi üstünlüğüyle böbürlenmesi ve birbirlerini alay edip eleştirmeleri diyaloglarla anlatılmıştır. Sazların (tanbura, ud, çeng, kopuz, yatugan, rebab, gıçek, kingire), benlik davasıyla çekişmesi meclisin ahengini bozunca büyük gürültü kopar. Meyhanenin pîri, bu münazarayı sona erdirmek için sazların hepsini azarlar, vahdet-i vücûd sırrını ve tevhidin önemini anlatır (Eraslan, 1986).

Ahmed-i Dâî Çeng-nâme 'de münazara üslubunu andıran bazı ifade kalıpları kullanmıştır. Ancak bu ifadelerde münazara üslubundaki ben-sen davası yoktur, çeng ve çengin hiçbir parçası diğerinden üstün olduğunu savunmaz. Hatta eserin sonunda her parça bir ağızdan derdini anlatmaya başlar. Çeng bu parçaların birlik sesidir, vahdet-i vücûd sembolüdür:

Benem ser-halka anlar bende-fermân

Kamu benden dutar âdâb u erkân

Bizi kim gördün uşta dört yâruz

Biribirümüze hoş destiyâruz (b. 1322-1323) 


\section{Sonuç}

Suriye'de Medinetü'n-Nevâ 'ir (Su dolabı șehri) diye bilinen Hama'ya seyahat eden İbn Saîd Mağribî, İbn Battûta, Abdurrahman Hibrî, Evliya Çelebi, Karacaoğlan, Hama'daki Âsi Nehri üzerine kurulu su dolaplarından bahsetmiştir. Dolab-nâme türünün oluşumuna Hama' daki tarihi bir eser olan Dolab-1 Muhammedî’nin etkisi büyüktür. Araştırmamız sonucu klasik Türk şiirinin farklı sahalarında rastlanabilen dolab-nâme türü hakkında vardığımız sonuçlar şöyle sıralanabilir:

1. Dolab-nâme türüne ilham veren Dolab-1 Muhammedî efsane değil, gerçek bir tarihî eserdir. Evliya Çelebi ve Kaygusuz Abdal Hama'da ziyaret ettikleri Dolab-1 Muhammedî'nin menkıbesini anlatmışlardır. Kaygusuz Abdal meşhur Dolab-nâme’sini bu Dolab-1 Muhammedî için yazmıştır.

2. Dinî-Tasavvufî Türk edebiyatı nazım türlerinden biri olan dolab-nâme, "Allah aşkının terennümünü ifade eden sorulu cevaplı manzume” olarak tarif edilir. Ancak türkülerde, nefeslerde ve dîvân şiirleri içinde dolab-nâme özelliği gösteren şiirler vardır. İncelediğimiz bir Hatay türküsü, dolab-nâme türünün sadece tekke edebiyatı içinde değerlendirilemeyeceğini, anonim halk edebiyatı ve âşık edebiyatı içinde de görülebileceğini göstermiştir.

3. Dolab-nâmenin bilinen ilk örneklerini birbirine yakın dönemde yaşayan Âşık Yunus ile XIV. asrın sonu XV. asrın başı arasında yaşadığı düşünülen Kaygusuz Abdal'ın söylediği kabul edilir. Kaygusuz Abdal'ınki didaktik olduğu için, Âşık Yunus'un Allah aşkıyla inleyip dönen dertli dolabından biraz farklıdır. Buna göre muhteva olarak dolab-nâme türünü şöyle âşıkâne ve hakîmâne olarak ikiye ayırabiliriz. Âşıkâne Dolab-nâme, Allah aşkının verdiği derdi âşıkâne bir üslupla anlatır. Bunun öncüsü Âşık Yunus’tur. Bu üslupta yazılan dolab-nâmede kesret-vahdet ilişkisi ve Elest Bezmi’ne özlem vardır. Hikemî Dolab-nâme ise, riyazât ve mücahede ile fani dünyaya aldanmadan beka yurdu olan ahireti ve Allah rızasını kazanmayı ögütler. Bu dolab-nâmenin öncüsü Kaygusuz Abdal'dir.

4. XVI. yüzyılda yaşayan Şeyh Emir Ahmed Hayâlî-i Gülşenî’nin 64 beyitle yazdığı Dolabnâme ise bu türün en uzun örneğidir. Bir sergüzeşt-nâme olarak da değerlendirebileceğimiz dolab-nâmeyi ise Kırım Hanı Gazi Giray (1554-1607) mesnevi nazım şekliyle yazmıştır.

5. Dolab-nâmenin tanımında su dolabı adının geçmemesi, şairlerin canlı-cansız başka varlıklarla da “Allah aşkının terennümü” için söyleşilebileceği anlamına gelir. Nitekim Ahmed-i Dâî'nin Çeng-nâme'si ve Pir Sultan Abdal'ın tanburu ile söyleştiği şiiri böyledir.

6. Dolab-nâme şiirlerinin muhtevasında su dolabının bir dert ile inlemesi, klasik Türk şiirine ilham vermiştir. Âşık kimliğiyle şairler kendilerini su dolabı ile özdeşleştirmişlerdir. 
Hakem Değerlendirmesi: Dış bağımsız.

Çıkar Çatışması: Yazar çıkar çatışması bildirmemiştir.

Finansal Destek: Yazar bu çalışma için finansal destek almadığını beyan etmiştir.

Peer-review: Externally peer-reviewed.

Conflict of Interest: The author has no conflict of interest to declare.

Grant Support: The author declared that this study has received no financial support.

\section{KAYNAKÇA/REFERENCES}

Abduvaliyeva, E. (2011). Bora Gazi Giray Han: Hayatı ve Eserleri. (Yayınlanmamış Doktora Tezi). Ankara: Ankara Üniversitesi.

Akdoğan, Y. (1979). Ahmedi Dîvânı ve Dil Hususiyetleri: Gramer Sentaks Sözlük. (Yayınlanmamış Doktora Tezi). İstanbul: İstanbul Üniversitesi.

Altınova, M. (2019). Azîzî Dîvânı ve Istanbul Şehrengizi’nin Sözlüğü (Băglamlı Dizin ve Isslevsel Sözlük).

(Yayınlanmamış Yüksek Lisans Tezi). Kütahya: Dumlupınar Üniversitesi.

Alvan, T. (1998). Hayâlî-i Gülşenî Dîvânı. (Yayımlanmamış Yüksek Lisans Tezi). İstanbul: İstanbul Üniversitesi.

Aksoyak, İ. H. Gelibolulu Âli Dîvânı, (https://ekitap.ktb.gov.tr) (05.09.2020)

Âşirefendizâde M. H. (2018). Ed-Dürerü'l-Müntehabâti'l-Mensûre fî-Islâhi'l-Galatâti'l-Meşhûre. Y1lmaz Y. (Haz.) Ankara: TDK

Bayram, Y. (2008). Amasya ya Vâli Osmanlı'ya Padişah Bir Şair: Adlî, Amasya: Amasya Valiliği Yayını.

Benli, Ş. (2019). Klasik Türk Edebiyatında Münazara, (Yayınlanmamış Doktora Tezi). İstanbul: İstanbul Üniversitesi, Türkiyat Araştırmaları Enstitüsü.

Boratav, P. N. (1983). Folklor ve Edebiyat 2 (1982), İstanbul: Adam Yayınlar1.

Çeltik, H. (2011). Ahmed-i Rıdvan Divanı. Ankara: Bizim Büro Yayınları.

Demir, A. (2016). Çăglar İçinde Antakya. Dafne Kitap.

Eraslan, K. (1986). “Ahmedî: Münâzara (Telli Sazlar Atışması)”, İstanbul Üniversitesi Edebiyat Fakültesi Türk Dili ve Edebiyatı Dergisi, (XXIV) 129-204.

Erünsal, İ. E. (2018). Tâcî-Zâde Ca fer Çelebi Dîvânı, (https://ekitap.ktb.gov.tr) (05.09.2020)

Evliya Çelebi b. Derviş Mehemmed Zıllî, (2011). Evliya Çelebi Seyahatnamesi, Cilt, I-II. R.Dankoff, R

\& Kahraman, S.A. \& Dağlı, Y. İstanbul: YKY Yayınları.

Fuat, M. (2001). Pir Sultan Abdal, İstanbul: YKY Yayınlar1.

Güzel A., \& Torun, A. (2003). Türk Halk Edebiyatı El Kitabı, Ankara: Akçă̆ Yayınları.

Güzel, A. (1999). Kaygusuz Abdal (Alâeddin Gaybî) Menâkibnâmesi. Ankara: TTK

Güzel, A. (2006). Din̂̂-Tasavvufî Türk Edebiyatı. Ankara: Akçağ Yayınları.

Güzel, A. (2006). Kaygusuz Abdal. Ankara: Akçağ Yayınları.

Güzel, A. (2013). “Kaygusuz Abdal'ın Eserlerinde Su' Motifi”. Suyun İzinde: Geleneksel Türk Sanatında ve Edebiyatında Su. Nurettin Demir (ed.). Ankara: Ankara Büyükşehir Belediyesi Yayını. 89-100.

Güzel, Abdurrahman (2000). Kaygusuz Abdal Divanı. Ankara: Milli Eğitim Yayınevi.

Horata, O. (1998). "Necati Bey’den Bâkîye Döne Döne”, Bilig Türk Dünyası Sosyal Bilimler Dergisi. (7), 44-66. 
İsmail Beliğ. (2009). Nuhbetü'l-Âsâr Li-Zeyli Zübdeti'l-Eş'âr. Abdulkadiroğlu, A. (haz.) Ankara: AKM Yayını. Kızıldağlı, E. (1943). Antakya Kapılarında. İstanbul: Ahmet Halit Kitabevi.

Küçük, S. (1994). Bâkî Divanı Tenkitli Basım. Ankara: TDK Yayınları.

Latîfî (2000). Tezkiretü'ş-Şuara ve Tabsıratü'n-Nuzemâ. Rıdvan Canım (Haz.). Ankara: Atatürk Kültür Merkezi Yayınları.

Mütercim Asım. (2009). Burhan-ı Katı. Öztürk, M. \& Örs, D. (Haz.). Ankara: TDK.

Oktay, Z. (2010). Kaygusuz Abdal'ın Mesnevî-i Baba Kaygusuz'u Tenkitli Metin ve Inceleme, (Yayınlanmamış Yüksek Lisans Tezi). İstanbul: Boğaziçi Üniversitesi.

Özbay, E. (2012). Asi Nehri Üzerindeki Su Yapıları: Nauralar. (Yayınlanmamış Doktora Tezi). İzmir: Ege Üniversitesi.

Özbay, E. (2012). “Antakya'nın Tarihî Su Dolapları Nauralara Işık Tutan Alvan Su Kemeri Kalıntısının Mimarî-Tarihî Analizi ve Restitüsyonu”. Sanat Tarihi Dergisi, XXI (2), 73-98.

Özcan Yurdalan, Ö. (2006). Naure Çarkı: Suriye Yolculuğu. Agora Yayınları. 107-110.

Öztelli, C. (1989). Pir Sultan Abdal Bütün Şiirleri, İstanbul: Özgür Dağıtım.

Öztürk, A. (2003), “Dinî-Tasavvufî Edebiyatımızda Dolapnâme Türü ve Ahmed Hayâlî’nin “Tolabnâme İsimli Kasîdesi”, Gazi Üniversitesi Çorum İlahiyat Fakültesi Dergisi, II (3). 87-101.

Riza Nour, (1935). "Kaïghousouz Abdal (Ghaïbi Bey)”, Türkbilig Revüsü, Revue De Turcologie, Tome II, Livre I. (5). 86-803.

Sâî Mustafa Çelebi. (2002). "Der Beyân-1 Bünyân-1 Çâh-1 Tolâb”. Yapılar Kitabı, Tezkiretü'l-Bünyan ve Tezkiretü'l-Ebniye. Hayati Develi (Haz.) İstanbul: Koçbank.

Sever, M. (2013), “Kaygusuz Abdâl’ın Menâkıbnâmesine ve Şiirlerine Göre İnsanın Manevî Eğitimi”. Karadeniz Uluslararası Bilimsel Dergi. 1(17). 58-68.

İlgürel, S. (1975) “Abdurrahman Hibrî’nin Menâsik-i Mesâlik'i”, İstanbul Üniversitesi, Edebiyat Fakültesi, Tarih Enstitüsü Dergisi. (6), 110-128.

Tancî, İ. B. M. E. A. (2004). İbn Battuta Seyahatnamesi. Aykut A. S. (Çev.) İstanbul: Yapı Kredi Yayınları. Tarlan, A. N. (1968). Zâtî Divanı. Cilt I, İstanbul: İstanbul Üniversitesi Edebiyat Fakültesi Yayını.

Tarlan, A. N. (1992). Ahmed Paşa Divanı. Ankara: Akçağ Yayınları.

Tarlan, A. N. (1992). Necatî Beg Divanı. Ankara: Akçağ Yayınları.

Tatcı, M. (2008). Asşı Yunus, İstanbul: H Yayınları.

Tekin, G. A. (1992). Ahmed-i Dâ'î Çengnâme-Inceleme. Tenkitli Metin. ABD: Harvard Üniversitesi Yakındoğu Dilleri ve Medeniyetleri Bölümü. Doğu Dilleri ve Edebiyatlarının Kaynakları: Türkçe Kaynaklar. (16).

Tekin, G. A. (2007). Eski Türk Edebiyatında Ağaç Motifi ve Sembolizmi. Edebiyat ve Dil Yazıları: Mustafa Isen'e Armağan, Ankara: Grafiker Yayınları.

Tulum, M. (2011). Meninski’nin Thesaurus'u ve XVII. Yüzyll İstanbul Türkçesi. Ankara: TDK.

Wagner, E. (1993). "Munazara”, The Encyclopaedia of Islam. (7), Leiden: E. J. Brill.

Yavuz, K. \& Yavuz, O. (2016). Muhibbî Dîvânı (inceleme-tenkitli Metin). İstanbul: Türkiye Yazma Eserler Kurumu Başkanlığı Yayınları.

Yıldırım, N. (2017). “Asi Nehri’nin Adı Üzerine Bir İnceleme”, Archivum Anatolicum (ArAn). Ankara Üniversitesi, 11(2). 77-88.

Y1lmaz, M. (2015). Mecmû'a-i Hikâyât Türk Dil Kurumu Kütüphanesi A 276 İnceleme - Metin - Sözlük -Tıpkıbasım, (Yayınlanmamış Yüksek Lisans Tezi), Adıyaman Üniversitesi. 144-147.

Yilmaz, Y. (1998). Hz. İsa Antakya Halkı ve Habib Neccar. Ankara: Asya Ofset.

Ziyaeddin F. (1927). "Sergüzeşt-i Kaygusuz Abdal”. Hayat Dergisi, (17). 7-8. 


\section{EK 1}

(Tatc1, 2008, s. 88-89)

1. Dolab niçün inilersin

Derdüm vardur inilerüm

Ben Mevlâ'ya âşı oldum

Derdüm vardur inilerüm ${ }^{6}$

2. Benüm adum dertli dolap

Suyum akar yalap yalap

Böyle emr eylemiş Çalap

Derdüm vardur inilerüm

3. Beni bir dağda buldılar

Kolum kanadum kırdılar

Dolaba lâyık gördiler

Derdüm vardur inilerüm

4. Balta zahm urdı ezelî

Soldı benzimün gazeli

Sorman bana bu su'âli

Derdüm vardur inilerüm

5. Bıçkıcılar bıçdı beni

Budağum yaprağum kanı

Âlemi yaradan Ganî

Derdüm vardur inilerüm

6. Dağdan kesdiler hizenüm

Düzdiler dürlü düzenüm

Eylenen aylak ozanum

Derdüm vardur inilerüm

7. Beni kodılar taşkına

Tuşmadum benden coşkına

Muhammed Ali aşkına

Derdüm vardur inilerüm
8. Dülgerler budağum yondı Her azâm yerine kond 1

Bu inildüm Hakk'dan geldi

Derdüm vardur inilerüm

9. Suyum alçakdan çekerüm

Dönüp yüksekden dökerüm

Görün şu ben ne çekerüm

Derdüm vardur inilerüm

10. Ben bir dağun ağaciyam

Ne tatliyam ne aciyam

Ben Mevlâ'ya duaciyam

Derdüm vardur inilerüm

11. Yaradan'dan hûnum vardur Evliyadan demüm vardur

Nefs gibi düşmanum vardır

Derdüm vardur inilerüm

12. Derviş Yûnus eydür âhı

Gözyaşı döker günâh1

Hakk'a âşıkam vallâhi

Derdüm vardur inilerüm

13. Yunus bunda gelen gülmez

Kişi muradına ermez

Bu fâni de kimse kalmaz

Derdim vardır inilerüm

6 Bazı metinlerde nakarat “Anun içün inilerüm” şeklindedir. 


\section{EK 2}

(Güzel, 1999, s. 124-126)

\section{KASÎDE-İ TOLÂB MİN-KELÂM-I KAYGUSUZ BABA SULTÂN KADDESALLÂH:}

1. Su'al itdüm bugün ben bir dolâba

Didüm niçün sürersün yüz bu âba

2. Neden bağrun delükdür gözlerün yaş Sebeb nedür sataşdun bu 'itâba

3. Karârun yok gice gündüz dönersün Dökersün derdlü gözlerden hûn-âba

4. Elif kaddün bükülmiş çenge dönmiş İnildüni düzeltmişsün rebâba

5. Gözün yaşı revân oldı seher-gâh Giceler varmadun bir lahza hâba
6. Niçün feryâd-ile zârı k1lursun Meger derdün senün gelmez hisâba

7. İnildünden delindi derdlü bağrun Figânundan ciger döndi kebâba

8. Nice virdi haber sana bu devran Ki derdün defteri sığmaz kitâba

9. Ne cevr itdi sana bu çarh-1 gaddâr Ki devr içre düşübsen bu 'itâba

10. Duhânundan boyandı göge gökler Firâkundan kara yirler türâba

11. Su'âl itdüm dolabun döndüginden Dönüben çün tolâb geldi cevâba

\section{CEVÂB-DÂDEN-İ TOLÂB BABA KAYGUSUZ SULTÂN}

1. Tolâb eydür eyâ çeşmüm çerâğ 1 İşidmege cevâbum aç kulağı

2. Benüm budur sorarsan ser-güzeştüm $\mathrm{Ki}$ ben yaylar idüm bir yüce tağı

3. İrişmezdi boyuma altmış arşun Belüme dahı on âdem kucağ1

4. Geçürmişdüm serâdan köklerümi Süreyyâ'ya yitürmişdüm budâğ1

5. Tokuz ay derneşüp bin dürlü kuşlar Budağumda tutarlardı otâğ 1

6. Öterdi tûti vü kumrı vü dürrâc Geçürdüm bir zaman bu niçe çağ 1

7. Hevâ murg-1 kebûter bağ gezerken Örülmiş 'ömr kuşunun tuzağ 1

8. Kazâ irdi meger dest-i kaderden Ki bir şahs irişüp çaldı bıçağı
9. Y1k1lup yatdum ol dem yüzüm üzre Kırıldı kalmadı budum budağı

10. Delüp boynuma takdılar kemendi Sürüdiler dolandum her sokağ 1

11. Nice müddet sokaklarda yüzime Gelüp giçen basarlardı ayağ 1

12. Yidi Eyyüb-veş bağrumı kurtlar Ciger kanun döker çeşmüm kapağı

13. Zekerriyâ gibi biçüb belümden Tolab içün düzetdiler yarağ 1

14. Temür mihlar dokunup yüregüme Kazâ desti ile çarhun çomağ 1

15. Tolab oldum gice gündüz dönerem Su üstinde tutar oldum otağ 1

16. İnilerem dün (ü) gün dost diyüben Gözüm yaşı sular bûstânı bağı 
17. Kime dost oldı devrân bu cihânda Ki sonra olmadı anunla bâğ 1

18. Felek kime tadurdı bir kaşuk bal $\mathrm{Ki}$ son uci sunar tas ile ağu

19. Süleymân'un sürerdi tahtına yel Kara toprağa koymışdur yatağı

20. Sikender kim cihânı Kâf -ber-Kâf Tutub hükmine sürerdi yasağ 1

21. Girüp zulmetde ister âb-1 hayvân Tolu zehr ile sundılar bayağı

22. Cihanda varlığı başdan başa hep Fenâ yurdı durur mihnet ocağı
23. Kanı Rüstem kanı Husrev kanı Sâm Belürmez birünün ucı bucağı

24. Bekâ yurdı degüldür ki bakasun Fenâ ehli tutar bunda otağı

25. Bu dünyâ bir büyûtu'l- 'ankebûtdur Pes ol oldı megeslerün tuzâğ 1

26. Olublar (Alâî) Gaybî bunda tekye kılan Hak'un fażlı durur ancak tayağı

27. Sabır seccâdesün ki altına salmış Tevekkülden kuşanmışdur kuşağ

28. Sözini Kaygusuz 'ârife söyle Ne bilsün şekkeri tana buzağ 1 


\section{EK 3}

(Alvan, 1998, s. 9-13)

\section{ŞEYH AHMED HAYÂLî-İ GÜLŞENÎ KASÎDE-Yİ DOLAB-NÂME}

1. Geçerken bir tolaba nâgehânî Duş oldum katı inler gördüm anı

2. İnildüsi beni medhûş kıldı Yakîn oldı ki cân virem revânı

3. Didüm var-1sa hem-derdümi buldum K'inildüsiyle doldurmış cihânı

4. Benüm derd-i dilümi kimse bilmez Velî bir pâre bu virür nişânı

5. Yakın varup su'âl itdüm tolaba Ne itdürdi sana bunca figânı

6. Nedür inildedügün zâr1-yıla Di tâ men dahi derdüm diyem anı

7. Didi hâlüm benüm derdüme şâhid Dün ü gün inlerem durman dolanı

8. Vücûdum deldiler yer yer mih ile Yaşum ile suvardılar cinânı

9. Cihân bağında bir ser-sebz-i ra'nâ Hırâmân serv-kadd iken güveni

10. Çemenlü çeşmede yaylada me'vâ İdüp hoş geçürürdüm her zemânı

11. Benüm sâyemde dilberler depemde Ohurdı bülbül ü kumru terâni

12. Bana hidmetde dâ'im unsûr-1 pâk Çehâr erkân ile beste-miyâni

13. Su hâk ile ayağımda beraber Od u yil yilmede her-sû devâni

14. Hirâmân ser-firâz u sebz-i ra'nâ Benüm kimi ola itme gümânı

15. Vücûduma bakup nâgeh güvendüm Deyüp benüm kimi bir dahi hani
16. Çenâr ü serv ü 'ar'ar ne ağaçdur Ki tûbâ reşk ider hûbluhda beni

17. Bu bir lahza gurûr ile özime Ne kıldum n'eyledüm n'itdüm gör ânı

18. Ki nâgeh gayret-i Hakk bir kişiye Nacah virmiş eline ol zamânı

19. Ayağumdan başuma bahdı bir kez Didi buldum diledüğüm söveni

20. Yigitlügime hiç rahm itmediler Çü geçdi kadd-i dil-cûmun avânı

21. Ne geldi başuma ol demde benüm Kulağ ur şimdi işit mâcerânı

22. Nacahla urdılar pâyıma bir kez Ayahdan saldılar men nev-civânı

23. Yer ü su vü kökümden ayru düşdüm Dahi virmediler bir dem amânı

24. Bununla kurtulam sandım fe'emmâ Kolum budum budadılar budanı

25. Yüz üzre toprağa saldılar ol dem Yalangaç günde kaldım yana yanı

26. Başumı kesdiler Yahyâ tek oldum Ayağ üzre durutdılar dolanı

27. Zekeriyyâ kimi bıçku uruben Başumdan ayağa biçüben anı

28. Vücûdum tahta tahta pâre pâre İdüp gezdürdiler deşt ü yabanı

29. Getürdiler birahdılar son ucı Beni bir şehre kim çohdur avânı

30. Yaturdum nice müddet kûçe içre Garîb ü bî-kes ü tenhâ vü fâni 
31. Cehûd u gebr ü tersâ vü mecûsî Yüzüme gözüme basdı tabanı

32. Birazdan aldılar çoh ekseriler Keser burgu vü biçgu vü sûhânı

33. Didiler getürün ol pür-gurûr1 Kesüp çarh idelüm dönsün sulanı

34. Getürdiler buraya nice üstâd Kesüp yonmağa cism-i nâ-tüvânı

35. Kimi bıçgu kimisi burgu-y-1la Kesüp biçüp düzetdiler dayanı

36. Hamusın ko vü gör bu nâ-tıraşı Ki bögrümden delüp sohmuşlar anı

37. Beni bir lahzâ râhat eylemez hiç Dolandurur dün ü gün yuvalanı

38. Nedür derdüm idem şerhini sana Ki bî-pâyân-durur anun beyânı

39. İki gün kime yâr oldı zemâne Ki itmedi ana çoh çoh ziyânı

40. Cihân bağında her kim gördi özin Revân oldı kara yer üzre kanı

41. Benüm deyü yaşayan bâğ u bûstân Gidüp özgeye koydı bu sitânı

42. Düzen durmaklıg içün tâk-1 eyvân Son ucı tutdı gûr içre mekânı

43. Hani Âdem hani Nûh ile İdrîs Halîlullah da terk itdi sü(k)kânı

44. Hani Ya 'kûb u İsmâ' îl ü İshâk Hani Dâvud ki inletdi cihânı

45. Süleymân-1 Nebî hani gözün aç Ki teshîr eylemişdür ins ü cânı

46. Hani İskender ü Mûsâ vü Îsâ Göçüp terk eylediler bu cihânı

47. Cihânda kimse bâkî kalsa idi Muhammed kala idi câvidânî
48. Ya hani bunca da'vâ eyleyenler Benümdür deyüben milk-i Keyânı

49. Hani Kâvus u Keykâvus u Behrâm Ya hani Hüsrev ol şâh-1 yegânî

50. Hani İsfendiyâr ü Rüstem-i Tûs Feridûn ya Süheyl-i İsfehânî

51. Hani Keyhüsrev-i şâh-1 Dilâver Ki öldürdi sıkup şîr-i jiyânı

52. Hani Câmasb u Cemşî̀ ü Siyâvûş Hani Kisrâ hani Behrâm-1 sânî

53. Hani Efrasyâb ol merd-i meydân Ki gürz ile yıhardı ejdehânı

54. Gelen geçer karâr itmez cihânda Koyup düşmenlerine hânumânı

55. Cihân kimseye bâkî kalmaz imiș Hakk'a vir gönlüni ko hâkdânı

56. Gerek şâh u fakîr ü bî-nevâ ol Yudar fark itmez ol şehden gedânı

57. Yirüp yirmek degildür dehre âdet Ki yuda eyüyi koya yamanı

58. Yerün karnı büyükdür nesne yirmez Yudar yohsulu andan bây olanı

59. Dayanma hânmân u mâl ü mülke Ecel irdükde komaz bunı anı

60. Çü cân kuşı kafesden ide pervâz Serîr-i hâke yeksân ide ânı

61. Elünden gelse sen de eylük eyle $\mathrm{Ki}$ rahmet ide adun işideni

62. Elünle virdigün kalur sana bes Olur düşmenlerün rızkı kalanı

63. Nice geldünse eyle gideceksin Ser-â-ser mülk idinsen bu cihânı

64. Yeter besdür Hayâlî itme tatvîl $\mathrm{Bu}$ fürkat-nâmeyi hatm it revânî 


\section{EK 4}

(Abduvaliyeva, 2011, s. 240-245)

\section{KIRIM HANI GAZİ GİRAY DOLAB-NÂME}

1. Yol üstinde yoluktum bir dolâba Didüm niçün sürersin yüz bu âba

2. Delinmiş bağrun u kaddün bükilmiş Gözün yaşı ayağına dökilmiş

3. Nedür âşık mısın var mı firâkın $\mathrm{Bu}$ gurbetde kimedür iştiyâkun

4. Geçer böyle senün leyl ü nehârun Ki yok midur elünde ihtiyârun

5. Nedür bâ'is hele böyle figâna Bükülmiş kâmetün dönmiş kemâna

6. Hem ağlarsın hem inlersin dem-â-dem $\mathrm{Bu}$ gizlü derdüni bilmez hîç âdem

7. Dolâb işitdi benden bu hitâbı Lisân-1 hâl ile virdi cevâb1

8. Habersiz âdemoğlu mâcerâdan Kazâdan bil dime çün ü çirâdan

9. Yüce dağlar idi evvel mekânum Benüm de var idi tâb u tüvânum

10. Akardı her zamânda deşt-i câri Revân olup ayağum çeşme-sâri

11. Tutup her yanumı kolum budağum Çemen üzre durup her dem ayağum

12. Başumda kumrı vü turâç öterdi Zemînimde nice güller biterdi

13. Libâsum geh yeşil gel al olurd1 Hazân vakti zerüm pâ-mâl olurdı

14. Benefşe baş ururdı sola sağa Nihâl-i nev-resim durup ayağa

15. Safâ ile tutup câmını lâle Saçardı cur'asını hâke jâle
16. Olup nergis gözi her gice bî-hâb Olurdı nukl-1 meclis anda 'unnâb

17. Esüp bâd-1 ecel nâ-geh yıkıldum Kesildi bîh-i ömrüm anda bildüm

18. Bükegelmez idi hergîz kemânum Y1kıldum kalmadı tâb u tüvânum

19. Hemân-dem kesidler kolum budağum Sürtmeg-çün biri deldi ayağum

20. Takup boynuma anda rismânı Ki bildüm kalmadı işret nişânı

21. Kanı ol mergzârum lâlezârum Dirîğâ getdi elden ihtiyârum

22. Meni kıldılar anda hâke yeksân Ki efgân eyleridüm gâh nâlân

23. Nice yıl geçdi vü cismüm kurıdı Yeşil tonum karardı vü çüridi

24. Zekeryâ tek beni andan biçerler İşit imdi bana ne iş geçerler

25. Kılup tahta meni hem mîh ururlar Ki cem 'olup dahi suya sürürler

26. Dönermen ol zamândur bu zamândur Bilürsin kim felek işi yamandur

27. Yedi Eyyûb tek bağrumnı kirmân Kazâya çâre ne söyle ne dermân

28. Sözümden ibret algıl sen de ey hân Fenâ milkinde varsız cümle mihmân

29. Gurûr itme sakın sen de cihâna Gülerdüm ben de nice nâtüvâna

30. Felek bir yedi başlı ejderhâdur Ki nakd-i ömr-i âdem hôd g1dâdur 
31. Nice mürsellere zehrün içürdi Nice yüzbin velî andan geçürdi

32. Nice şehler gelür anda olur mât Murâd üzre sürülmez bunda hîç at

33. Ne hôş dimiş bu ebyâtı bir üstâd Ki her demde anun rûhı ola şâd

34. Dil-âverler cihâna doymadılar Zamânun cümlesine doymadılar

35. Ki aldanma arûs-1 dehre zinhâr Nice arslan helâk eyler o murdâr

36. Ne hâl olsa ana dil virme bâri Vefâlu'dip bu kahbe rûzigârı
37. Geçürme gaflet ile rûzigârun Ki var iken elünde ihtiyârun

38. Dilersin kim irişesin kemâle Tevekkül kıl her işde Zü'l-celâl'e

39. İki âlemde istersen ferâgat Akıt gözden yaşını eyle tâ' at

40. Sözün hatm it yeter didün Gazâyî Ki tâ' at kıl dile Hakk'dan rızâyı

41. Rizâ vir her ne kim gelse kazâdan Hüdâ'dan bil Hüdâ'dan bil Hüdâ'dan 


\section{Ek 5}

(Öztelli, 1989, s. 367-368)

1. Ali Ali der de dönersin dolap Ne inlersin dolap, derdin nerende Yârdan mı ayrıldın, yoksa ilinden Ne inlersin dolap, derdin nerende

2. Dolap Hak, dedi de indi ırmă̆a Cehd etti Imamlara su vermeğe Muhammed'in hub cemalin görmeğe Ne inlersin dolap, derdin nerende

3. Sana bir ustanın eli mi değdi Yoksa bir hoyradın dili mi değdi Yaz bahar ayının seli mi değdi Ne inlersin dolap, derdin nerende

4. Seni kim kesti, getirdi yerinden Dağlar, taşlar inileşir zârından Seni kim ayırdı nazlı yârından Ne inlersin dolap, derdin nerende

5. Sana, durma dön mü dedi üstâdın Dağı, taşı yıkar senin feryâdın Dönerken taşı mı deldi hoyradın Ne inlersin dolap, derdin nerende

6. Böyle mi olur aşk hali, ahvali Vardl gamzelerin, irganur dalı Şimdi semah döner Urum Abdalı Ne inlersin dolap, derdin nerende

7. Pir Sultan Abdal'ım, aşka mı uydun Yoksa nazlı yârdan haber mi duydun Yârdan mi ayrıldın, ne idi derdin Ne inlersin dolap, derdin nerende

8. Pir Sultan'ım âhım arşa dayandı Hasret nârt ile yüreğim yandl Yoksa Hüseyin'den haber mi geldi Inilersin dolab derdin ne senin ${ }^{7}$

7 Bu kısımla beraber şiir, sözleri değişmiş halde türkü olarak da okunmaktadır. 